\title{
Sedimentological and palaeohydrological responses to tectonics and climate in a small, closed, lacustrine system: Oligocene As Pontes Basin (Spain)
}

\author{
A. SÁEZ and L. CABRERA \\ Department of Stratigraphy, Palaeontology and Marine Geosciences, Research Group of Geodynamics \\ and Basin Analysis, Faculty of Geology, University of Barcelona, E-08028 Barcelona, Spain \\ (E-mail: alberto@natura.geo.ub.es)
}

\begin{abstract}
A small, closed, lacustrine system developed during the restraining overstep stages of the Oligocene As Pontes strike-slip basin (Spain). The increase in basin accommodation and the headward spread of the drainage, which increased the water input, triggered a change from shallow, holomictic to deeper, meromictic conditions. The lower, shallow, lacustrine assemblage consists of mudstone-carbonate cycles recording lacustrine-palustrine ramp deposition in a saline lake. High Sr content in some early diagenetic calcites suggests that aragonite and calcite made up the primary carbonate muds. Early dolomitization took place together with widespread pedogenic activity. The upper, deep, freshwater, lacustrine assemblage includes bundles of carbonateclay rhythmites and fine-grained turbidite beds. Primary calcite and diagenetic siderite make up the carbonate laminae. The $\mathrm{Mg}$ content of the primary carbonates records variations in $\mathrm{Mg} / \mathrm{Ca}$ ratios in lacustrine waters. $\delta^{18} \mathrm{O}$ and $\delta^{13} \mathrm{C}$ covariance trends in calcite reinforce closed drainage conditions. $\delta^{18} \mathrm{O}$ data indicate that the lake system changed rapidly from short-lived isotopically light periods (i.e. from seasonal to pluriannual) to longer steadystate periods of heavier $\delta^{18} \mathrm{O}$ (i.e. from pluriannual to millennial). The small $\delta^{13} \mathrm{C}$ changes in the covariant trends were caused by dilute inflow, changing the contributions of dissolved organic carbon in the system and/or internal variations in lacustrine organic productivity and recycling. In both shallow and deep carbonate facies, sulphate reduction and methanogenesis may account, respectively, for the larger negative and positive $\delta^{13} \mathrm{C}$ shifts recorded in the early diagenetic carbonates (calcite, dolomite and siderite). The lacustrine system was very susceptible to high-frequency, climatically forced water balance variations. These climatic oscillations interfered with the lowfrequency tectonic and morphological changes in the basin catchment. This resulted in the superposition of high-order depositional, mineralogical and geochemical cycles and rhythms on the lower order lacustrine infill sequence.
\end{abstract}

Keywords Carbonates, closed drainage, hydrology, lacustrine environment, rhythmites, stable isotopes.

\section{INTRODUCTION}

Sedimentological, mineralogical and geochemical data from ancient and recent lacustrine sequences can be used in palaeoclimatic and palaeoenvironmental interpretation. Geochemical analyses of carbonate minerals are commonly used for palaeoenvironmental purposes, given that the geochemical composition of primary lacustrine carbonates records the complex interplay between basin hydrology, morphology and biogenic productivity (e.g. Talbot, 1990; Talbot \& Kelts, 1990; Johnson et al., 1991; Valero-Garcés et al., 1995; Li \& Ku, 1997; Utrilla et al., 1998). 
Climate is one of the major allogenic controls on short-term hydrologic change in lakes and the resulting mineralogical and geochemical records. Moreover, tectonics and drainage evolution also exert a major influence on lacustrine basin morphology and hydrology and can significantly change the mineralogical and geochemical record. Nevertheless, the response of lacustrine systems to simultaneous climatic and tectonicmorphological forcing is poorly understood, especially in large lacustrine systems, where these factors interact over large areas and result in complex depositional records.

The study of ancient, tectonically forced, small lacustrine systems may help to unravel some aspects of the long- to short-term influence of tectonics, morphology and climate on the evolution of lakes. Small lacustrine systems are very sensitive and readily affected by even minor tectonic or climatic changes. Owing to their reduced dimensions, it may be easier to constrain the relative influence of interacting tectonics, drainage evolution and climate on their depositional records. Following this approach, this paper deals with the analysis of the depositional, palaeoenvironmental and palaeohydrological evolution of the Oligocene As Pontes lacustrine system. One of its aims is to establish the response of this system to the short- to long-term (i.e. from annual to several hundred kyr) tectonic, morphological and climatic changes that affected the As Pontes basin catchment system.

\section{GEOLOGICAL SETTING}

The Tertiary As Pontes Basin is a small $\left(12 \mathrm{~km}^{2}\right)$ alluvial-lacustrine basin that developed in a NW- to SE-oriented dextral strike-slip fault system in north-west Spain (Cabrera et al., 1996). It is bounded to the north by E-W to NW-SE oriented thrusts, whereas its southern margin is defined by an unconformity between the up to $400 \mathrm{~m}$ thick Tertiary basin infill and the Precambrian-Palaeozoic metamorphic basement (Fig. 1). The early evolutionary stages of the basin took place in a restraining overstep (Fig. 2), which later evolved into a restraining bend situation (Ferrús, 1998).

The palaeobiological record of the As Pontes Basin demonstrates that the Oligocene palaeoclimate in NW Spain was subtropical, warmer than the present and probably with dry and rainy seasons (Medus, 1965; Baltuille et al., 1992; Cabrera et al., 1994). The heavy mineral assemblages yielded by the alluvial facies suggest that the basin catchment drainage spread significantly from the early to the late basin evolutionary stages, although the lithology of the metamorphic and igneous rocks in the source areas was similar to the present (Barsó et al., 2000). Therefore, it can be assumed that the regional water chemistry was also similar, although with minor differences resulting from diverse climatic, drainage and relief conditions. Present surface run-off and groundwater inputs are characterized by major $\mathrm{HCO}_{3}^{-}$and $\mathrm{Ca}^{2+}$ with lesser amounts of $\mathrm{Mg}^{2+}, \mathrm{Cl}^{-}$, $\mathrm{SO}_{4}^{2-}$ and $\mathrm{Na}^{+}$(Fernández et al., 1983).

The basin infill developed over 7 My mainly from Late Oligocene to Early Miocene (Huerta et al., 1997). It is divided into five major units on the basis of the relative abundance of lacustrine and marsh deposits and of the geometric tectonosedimentary relationships between the infilling sequences and the tectonic structures in the basin (Cabrera et al., 1996; Ferrús, 1998). Thus, Units 1, 2 and the lower part of Unit 3 filled two main depocentres (eastern and western), separated by a tectonic threshold bounded by an E-W thrust and a N-S normal fault (Fig. 2a and b). The upper part of Unit 3 and Units 4 and 5 gradually spread throughout the basin and finally buried this threshold and the previously active tectonic structures (Fig. 1b). Unit 1 records widespread lacustrine and/or swamp conditions, whereas Units 2-5 record mainly alluvial and swamp zones with no significant lacustrine deposition.

According to magnetostratigraphic data, the sedimentation of the alluvial-lacustrine assemblages in Unit 1 lasted up to 1.5 My (Huerta et al., 1997). This deposition took place in two subbasins, which were controlled by active thrusts and normal faults and surrounded by small alluvial fans (Figs 1, 2a and b). This tectonosedimentary arrangement, together with the overall water input/output ratio, gave rise in the eastern subbasin to a closed drainage lacustrine system (Ferrús, 1998). Unit 1 consists of up to $100 \mathrm{~m}$ of sediment that accumulated along the northern sub-basin areas, whereas the unit wedges towards the southern basin margin and onlaps the basement, which is locally overlain by thin basal colluvial breccias (Fig. 2c, assemblage Sc). This unit is split into two subunits $(1 \mathrm{~A}$ and $1 \mathrm{~B}$, Fig. 2c) and includes five major facies assemblages (Table 1; Figs 2 and 3). Assemblage 1 (gravels, sandstones and mudstones) records deposition on small, marginal alluvial fans. Assemblage 2 (cyclically arranged mudstones, marls, carbonates and rhythmites) constitutes most of Subunit $1 \mathrm{~A}$ and records deposition in shallow lacustrine- 
Fig. 1. (a) Geological map of the As Pontes strike-slip restraining bend basin showing the main tectonic structures that affect the basement. Note the strike-slip fault and associated thrusts, which bound the northern basin margin, the $\mathrm{N}-\mathrm{S}$ oriented normal faults and the E-W and NE-SW oriented thrusts. See location of wells represented in the cross-section in Fig. 2c. (b) Stratigraphy of the basin showing the main depositional facies and stratigraphic units (see arrows for location in Fig. 2a).
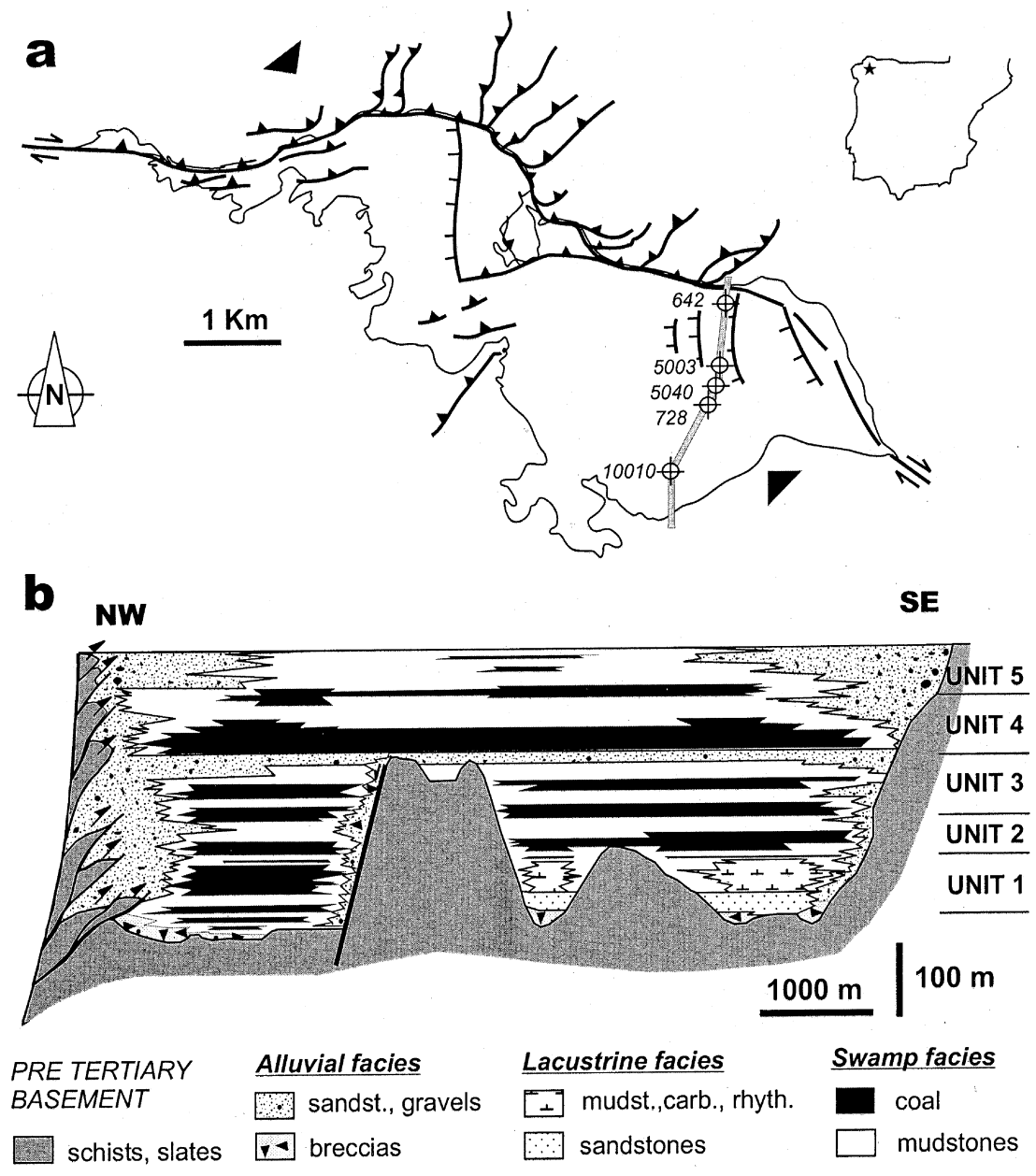

palustrine ramps. Assemblage 3 (laminated organic-rich facies) records deeper lacustrine deposition and constitutes most of lower Subunit 1B, which overlies a laterally extensive erosive surface developed at the top of Subunit 1A. The coaly bioclastic mudstone facies (assemblage 4) constitutes the upper part of Subunit 1B and records sedimentation on marginal lacustrine benches that prograded through gentle, lowgradient basinward slopes into the open offshore lacustrine zones (Fig. 3b). Assemblage 4 includes an olive green, fine-grained bed, which is a good reference level to correlate well cores. Finally, the mudstones, coaly mudstones and coal of assemblage 5 record the development of marshes at the top of lacustrine benches (Cabrera et al., 1995).

The lacustrine assemblages 3 and 4 are characterized by the widespread occurrence of primary and early diagenetic carbonate minerals, suitable for analysing the trends of the basin palaeohydrology. The following sections are dedicated to the detailed description and interpretation of this record.

\section{SAMPLING AND ANALYTICAL TECHNIQUES}

The massive palustrine-lacustrine facies in Unit 1 were sampled from continuous cores from five wells (Fig. 2c) with an average sample spacing of $20 \mathrm{~cm}$. The laminated lacustrine facies were sampled with similar spacing by extracting clay and carbonates from 17 clay-carbonate laminated bundles. The carbonate laminae were sampled using a microdrill.

Fifty selected carbonate and clay samples were studied using scanning electron microscopy (SEM; Hitachi S2300 and Jeol JSM840, equipped with an AN10000 Link energy-dispersive and X-ray microanalyser). Energy-dispersive analyses were carried out to check mineralogy and chemical composition.

The quantitative estimation of carbonate contents was carried out by decomposition of the samples with $\mathrm{HCl}$ and titration of excess acid with $\mathrm{NaOH}$ using a 702SM Trinitro automatic titrator. Bulk mineralogical composition of 189 

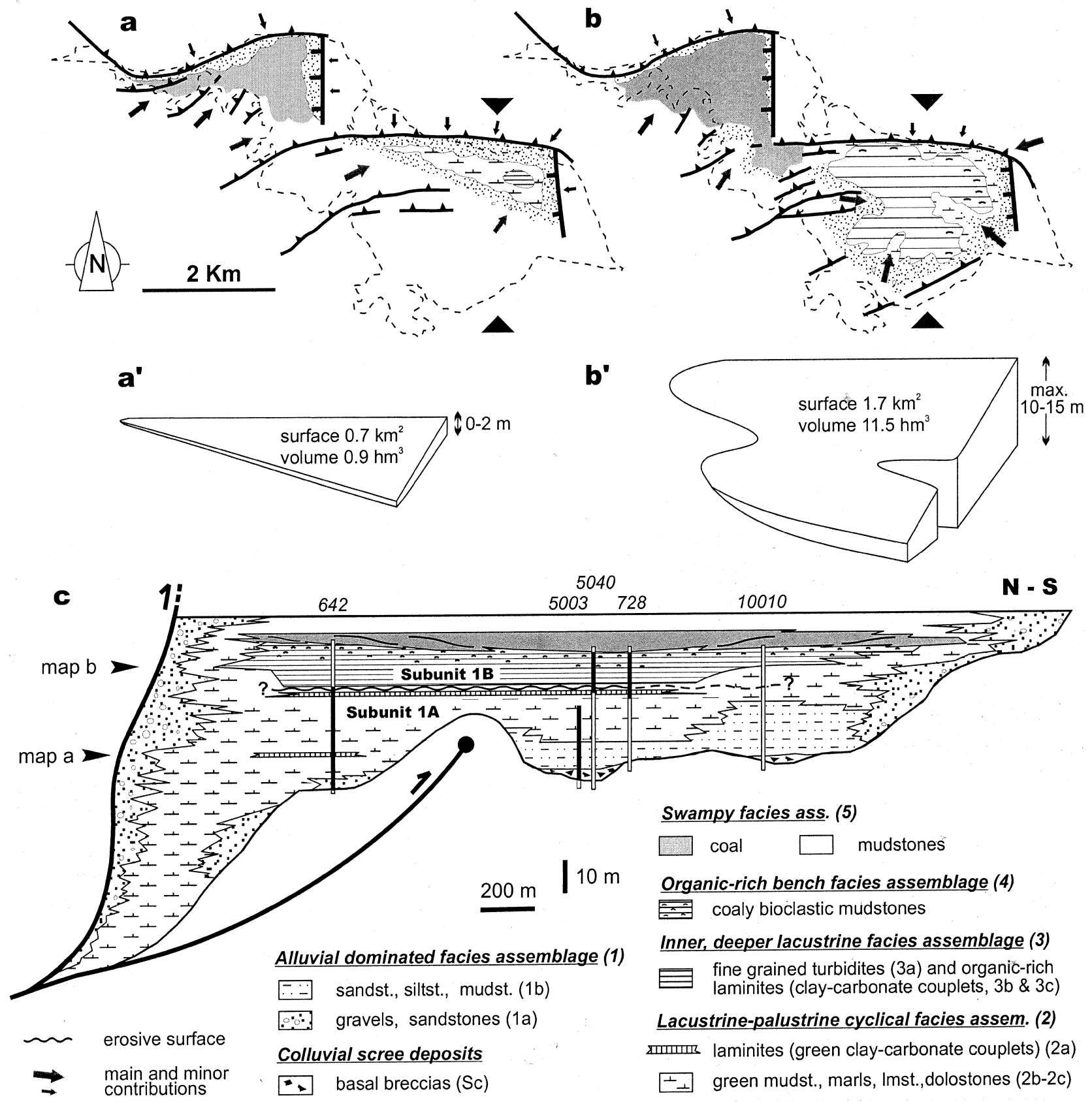

Fig. 2. Palaeogeographic sketches of the As Pontes Basin during Unit 1 deposition. (a and a') Lower part of Unit 1 (Subunit 1A) characterized by a minor water body and the development of palustrine and shallow lacustrine ramp environments. (b and b') Upper part of Unit 1 (Subunit 1B) characterized by a larger water body and the spreading of deeper lacustrine environments fringed by prograding benches. Note the persistence of marsh-swamp environments in the western sub-basin. (c) Transverse stratigraphic cross-section of the eastern sub-basin showing the facies assemblage relationships in Unit 1 (see location triangles in a and b). See well locations in Fig. 1a.

carbonate samples was determined by X-ray diffraction (XRD) using a Siemens D500 diffractometer. The composition of carbonate samples was also determined by standard XRD semiquantitative methods (Chung, 1974).
The molar percentage of $\mathrm{Mg}$ in calcites and dolomites was determined using X-ray diffractograms, by measuring the position of the $d_{104}$ peak relative to an internal quartz standard (Lumsden, 1979). When the sample volume was sufficient 


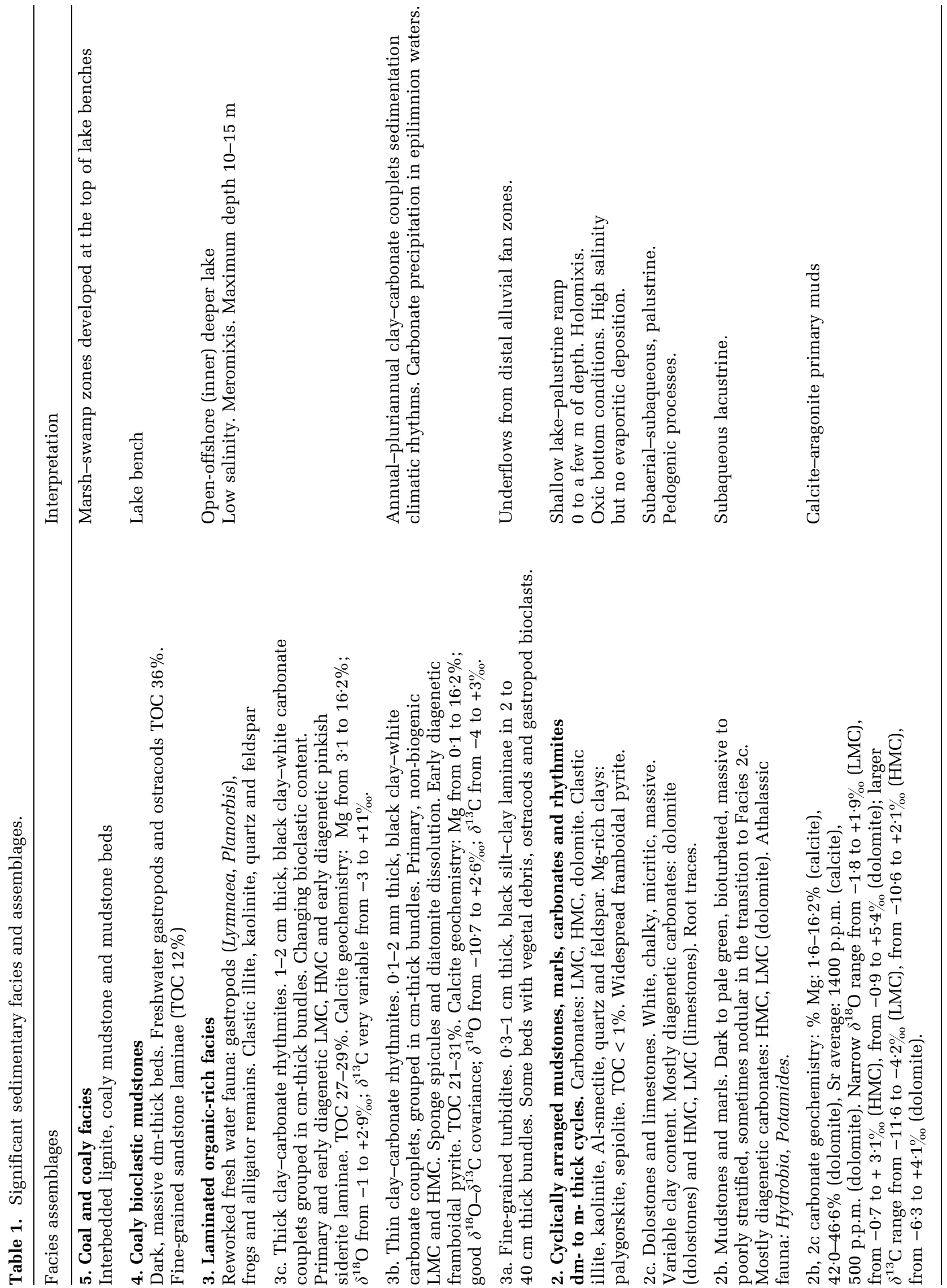




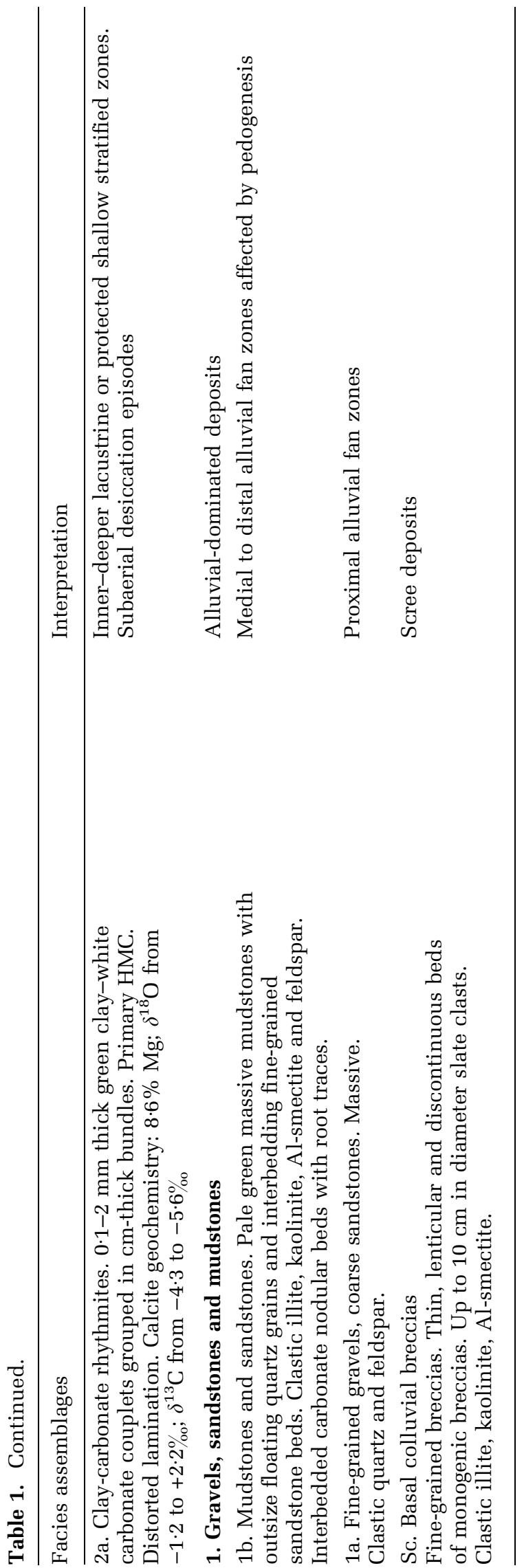

and the carbonate content $>10 \%$, the Sr content of the carbonates was determined for non-laminated, monomineral samples by means of atomic absorption spectrometry. The carbonate was digested in $5 \mathrm{~N} \mathrm{HCl}$ for $24 \mathrm{~h}$.

The total organic carbon (TOC) content of 108 samples was determined with an NA1500 elemental organic analyser, coupled to a gas chromatograph.

Oxygen and carbon isotopic relationships were established on monomineralic inorganic carbonate samples or on samples with $<5 \%$ of other carbonate minerals. Isotopic analyses were carried out in a VG-Isotech SIRA-II ${ }^{\mathrm{TM}}$ spectrometer. Organic matter was removed by roasting in a vacuum oven at $400{ }^{\circ} \mathrm{C}$ for $4 \mathrm{~h}$. Sulphur was extracted through reaction with $\mathrm{AgPO}_{4} \cdot \mathrm{CO}_{2}$ (McCrea, 1950) and $\mathrm{H}_{3} \mathrm{PO}_{4}$ at $25^{\circ} \mathrm{C}$ for $3 \mathrm{~h}$ for calcite samples and at $50{ }^{\circ} \mathrm{C}$ for $12 \mathrm{~h}$ for dolomite samples. Analytical precision for the carbonate standard measurements was $\pm 0.02 \%$ for $\delta^{13} \mathrm{C}$ and $\pm 0 \cdot 12 \%$ for $\delta^{18} \mathrm{O}$. The isotopic data are expressed in delta notation relative to PDB.

\section{LACUSTRINE-PALUSTRINE CYCLICAL RAMP DEPOSITS}

\section{Facies description}

Facies assemblage 2 (Table 1), which includes scarce thin laminated clay-carbonate couplets (Facies 2a), mainly consists of massive green mudstones and marls (Facies 2b), which alternate with whitish, chalky limestone and dolostone beds (Fig. 3a, Facies 2c). The mudstone-carbonate cycles range from a few decimetres up to a few metres in thickness, with maximum frequency around $0.5 \mathrm{~m}$, and can be truncated or symmetrical (Fig. 3a).

The lacustrine green clay-carbonate couplet Facies 2a includes carbonate laminae made up of polyhedral and heterometric crystals, ranging from a few to $10 \mu \mathrm{m}$ in size. The couplets are grouped into thin bundles of laminae, which occur at different stratigraphic locations (Fig. 2). The mudstones and marls (Facies 2b) often show monospecific gastropod accumulation horizons (Hydrobia) in addition to other gastropods (Potamides) and minor remains of charophytes. Mudstones are organic poor with the samples yielding TOC values below 1\%. The whitish carbonate beds (Facies 2c) are micritic and show greenish shades. They lack visible primary structures and are homogeneous except for occasional 

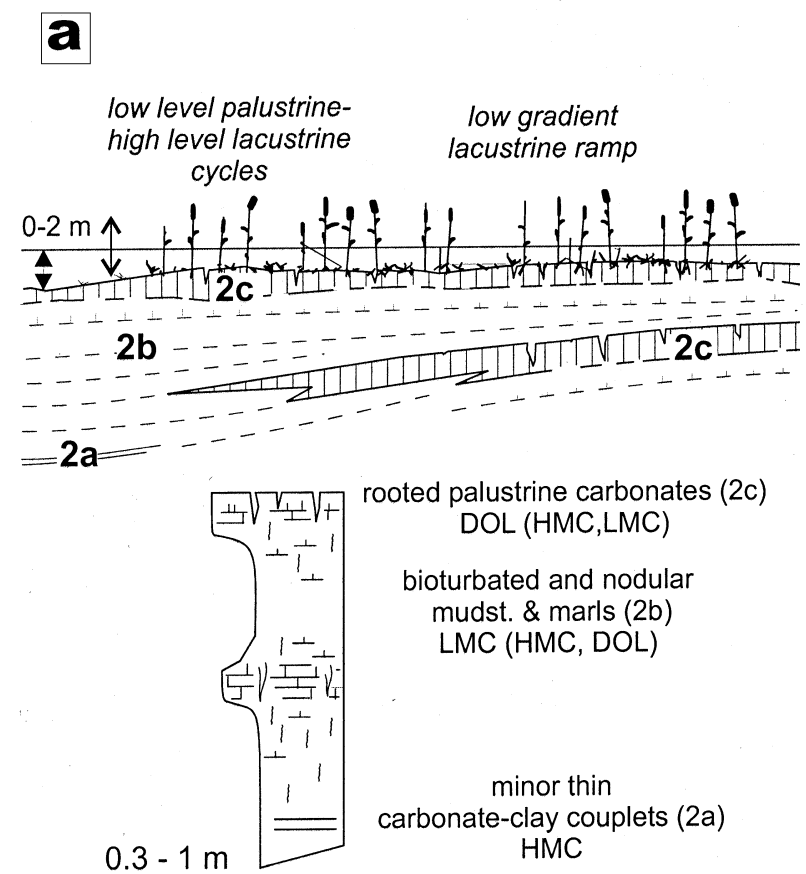

b
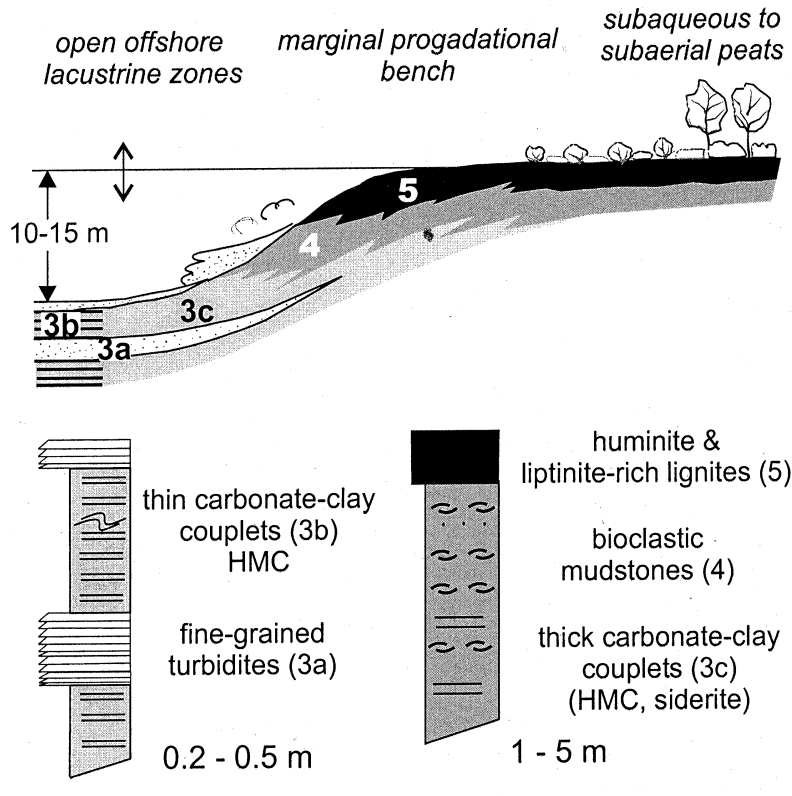

Fig. 3. (a) Palustrine-shallow lacustrine-dominated ramp model for deposition of the cyclically arranged mudstones and carbonates. (b) Depositional model of the deeper, lacustrine-dominated evolutionary stage. Both models display the ideal sequential arrangement of the most widespread facies, which are displayed here with their main mineralogical characteristics.

fractures (i.e. vertical and horizontal skew planes, Brewer, 1964; and root traces, Freytet \& Plaziat, 1982).

\section{Carbonate mineralogy, fabric and $\mathrm{Mg}-\mathrm{Sr}$ content}

The mineralogy of the carbonate laminae in Facies 2a was determined for three laminae from a bundle in the upper part of Subunit 1A (Fig. 5, bundle 1). High Mg Calcite (HMC) was the only carbonate phase recorded, with an average $\mathrm{Mg}$ content of $8 \cdot 6 \%$.

Most of the mudstone-carbonate cycles (Figs 3a and 4a) show a clear predominance of Low $\mathrm{Mg}$ Calcite (LMC) or HMC over dolomite in the lower mudstone beds in the cycles, whereas more varied occurrences of LMC, HMC and dolomite characterize the carbonate beds, with dolomite dominant in dolostones (Figs 3a and 5). Siderite is scattered and occurs in small amounts in $25 \%$ of the samples. A small amount of bioclastic aragonite is also present (accumulations of gastropod shells in the mudstones).

SEM images of the marl beds (Facies 2b) show scattered calcite and dolomite crystals embedded in a clay-dominated matrix. Some of the calcite crystals are euhedral with equigranular rhombohedral habits, ranging from 1 to $5 \mu \mathrm{m}$ in size, whereas others do not have well-developed faces. Dolomite crystals are readily recognized despite their small size (from 0.8 to $2.5 \mu \mathrm{m}$ ); they are typically single homometric and with a rhombohedral or polyhedral habit. Palygorskite is widespread and displays a clustered-fibrous habit, with fibres clearly adapting to the dolomite crystal surfaces (Fig. 4c).

The dolostones and limestones (Facies 2c) are massive, fine-grained $(\approx 3 \mu \mathrm{m}$ crystals $)$ beds. Limestones generally have anhedral-subhedral calcite. Dolostones display homometric subhedral-euhedral dolomite crystals with a good intercrystalline porosity (Fig. 4b).

The Mg content in calcites from Facies $2 \mathrm{~b}$ and 2c ranges from $1 \cdot 6 \%$ to $16 \cdot 2 \%$. Dolomites are nonstoichiometric and $\mathrm{Ca}$ rich with $\mathrm{MgCO}_{3}$ ranging from 42.0 to $46.6 \mathrm{~mol} \%$ (Fig. 5). The Sr content of the calcites ranges from 400 to 1500 p.p.m., whereas dolomites have lower values (500 p.p.m. on average). The calcite $\mathrm{Mg}$ and $\mathrm{Sr}$ content trends are concealed and altered in the middle part of Subunit 1A by the superimposed dolomitization (which interrupts the calcite record) and the presence of four bioclastic samples, which include aragonite (resulting in anomalous $\mathrm{Sr}$ maxima ranging from 2500 to 4000 p.p.m.; Fig. 5). Nevertheless, a $\mathrm{Mg}-\mathrm{Sr}$ enrichment trend occurs in the lower part of the 

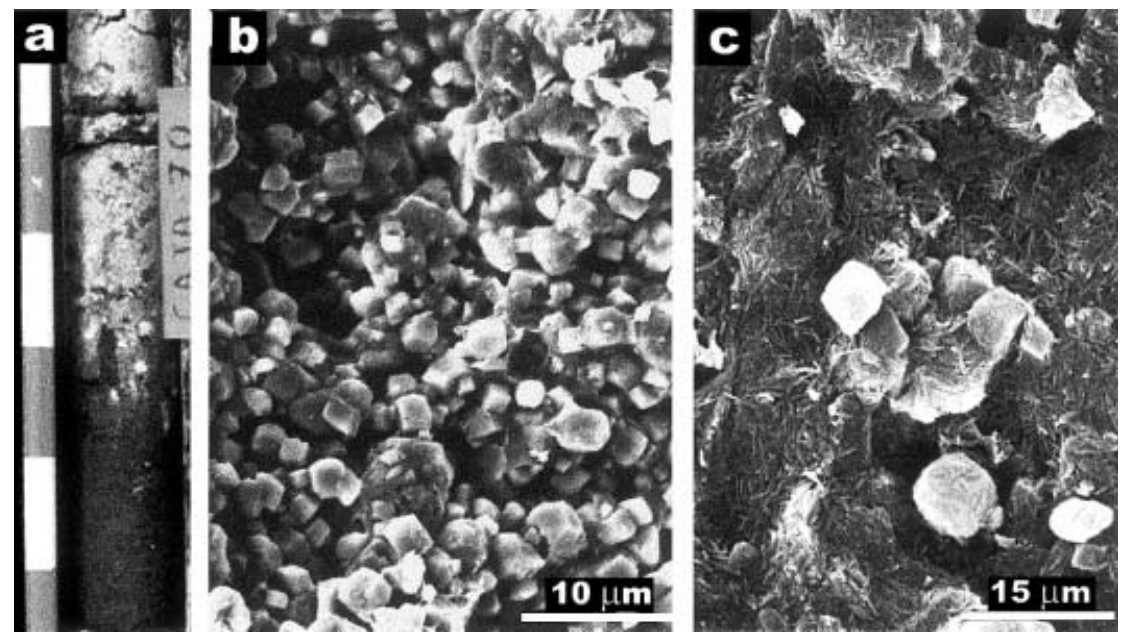

Fig. 4. (a) Well core showing the palustrine-lacustrine shallowing-deepening trends of Facies Assemblage 2 (Subunit 1A). The lighter, whitish palustrine carbonate facies (mostly dolomite) display cracks and root traces. The darker, green beds correspond to shallow lacustrine mudstones and marls. Scale bar on the left is $55 \mathrm{~cm}$ in length. (b) SEM view of equigranular, rhombohedral and polyhedral dolomite crystals in the dolostone beds in Facies 2c. (c) SEM view of scattered dolomite crystals surrounded by palygorskite fibres in carbonate-rich mudstones in Facies $2 \mathrm{~b}$.

subunit, whereas a $\mathrm{Mg}-\mathrm{Sr}$ depletion trend is recorded in the upper part (Fig. 5).

\section{Oxygen and carbon isotopic results}

The $\delta^{18} \mathrm{O}$ values recorded in the carbonate laminae from Facies 2a (bundle 1) range from $-1 \cdot 2$ to $+2 \cdot 2 \%$, whereas the $\delta^{13} \mathrm{C}$ values range from $-4 \cdot 3$ to $-5 \cdot 6 \%$ o (Table 1, Fig. 6). The $\delta^{18} \mathrm{O}$ values in the calcites from Facies $2 \mathrm{~b}$ and $2 \mathrm{c}$ range from $-1 \cdot 8$ to $+3 \cdot 1 \%$ (Figs 5 and 6). Dolomites have higher $\delta^{18} \mathrm{O}$ values (from -0.9 to $+5 \cdot 4 \%$ ). The $\delta^{13} \mathrm{C}$ values of carbonate minerals in the mudstone-carbonate cycles show a wider range of variation (from $-11 \cdot 6$ to $+4.1 \%$ ). LMC, HMC and dolomites have average $\delta^{13} \mathrm{C}$ values of $-7 \cdot 5,-5 \cdot 0$ and $-0.9 \%$ respectively (Fig. 6).

\section{Mineral composition of the (original and early diagenetic) carbonate muds}

The textural, mineralogical and geochemical features of the carbonate crystals and crystal clusters that make up the carbonate laminae of Facies 2a, compared with the carbonate laminae described previously in other case studies (Hsü \& Kelts, 1978; Anadón et al., 1988), show that they are mainly primary in origin and resulted from HMC precipitation in the water column. In contrast, the textural and geochemical features of the dolomiteand calcite-bearing facies in the mudstonecarbonate cycles (Facies 2b and 2c) and their close relation to the palustrine facies suggest an early diagenetic origin linked to interstitial carbonate precipitation, and to pedogenetic processes affecting calcite-aragonite-dominated original carbonate muds. The probable occurrence of a significant aragonite-dominated precursor (ADP) in the original carbonate muds is supported by the high Sr contents (higher than 1500 p.p.m.) in most of the non-bioclastic calcite-dominated deposits (Lasemi \& Sandberg, 1993; Wright et al., 1997).

A number of authors have argued that dolomite can be formed by direct precipitation at low temperatures and under special conditions of highly supersaturated waters with a high $\mathrm{Mg} / \mathrm{Ca}$ ratio and an elevated carbonate/bicarbonate concentration (Hardie et al., 1978). Last (1990) interpreted the origin of most lacustrine dolomite as primary (deposited directly from the lake waters or from interstitial porewaters), while maintaining that very few of the occurrences contain adequate petrographical evidence of a true secondary (i.e. replacement) origin. In fact, it is almost impossible to distinguish between primary and very early diagenetic dolomite in lacustrine evaporite settings (De Deckker \& Last, 1988). The As Pontes dolomites are fine grained, subhedral to anhedral and non-stoichiometric. They show low $\Delta \delta^{18} \mathrm{O}_{\text {DOL-CAL }}$ average values, which are consistent with the experimental differences in the oxygen isotopic fractionation coefficient existing between calcite and dolomite when secondary dolomite is produced by the replacement of pre-existing calcite under isotopic equilibrium and low temperature conditions (Fritz \& Smith, 1970; Matthews \& Katz, 1977; 

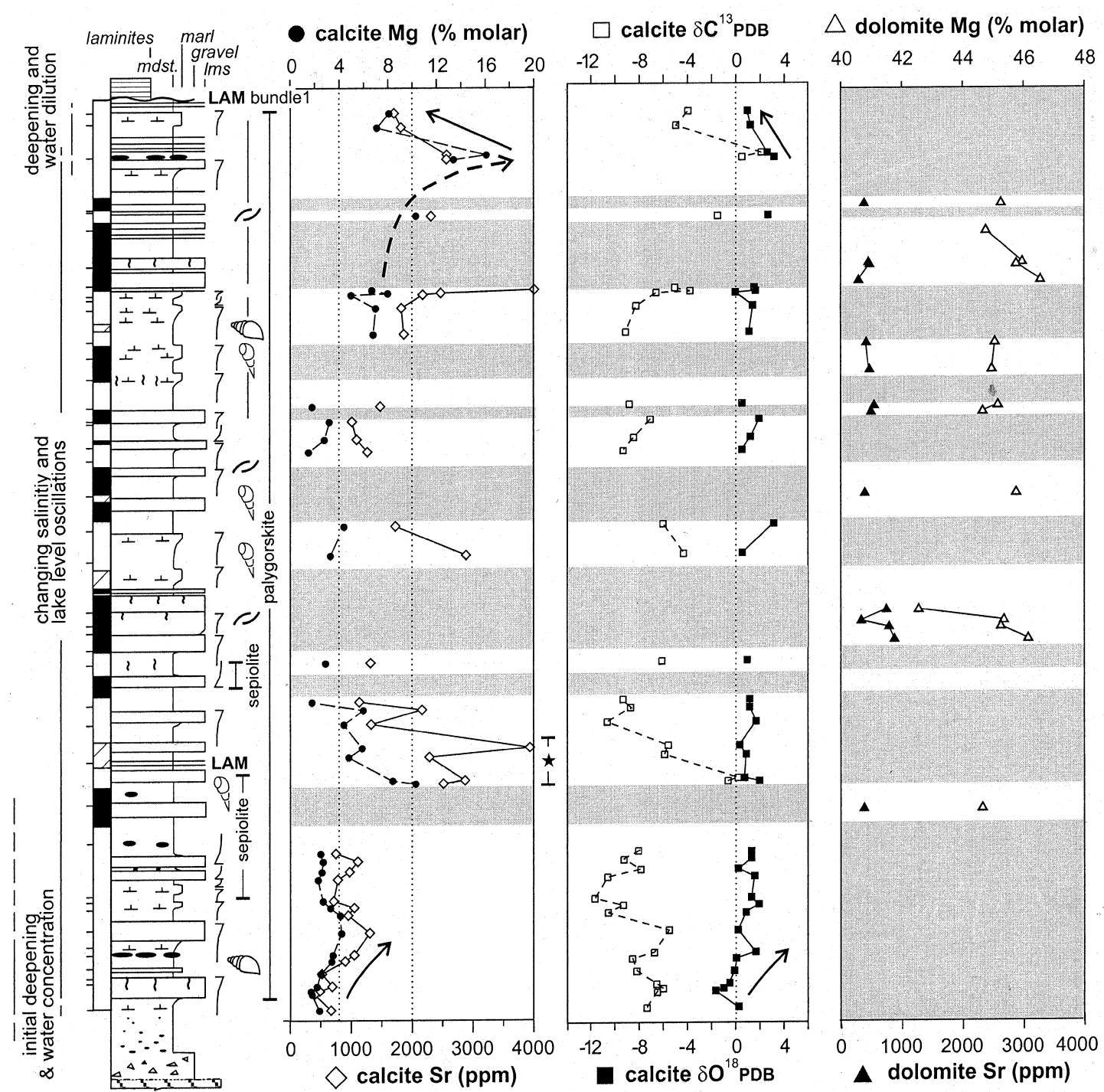

dolomite $\delta \mathrm{C}^{13}$
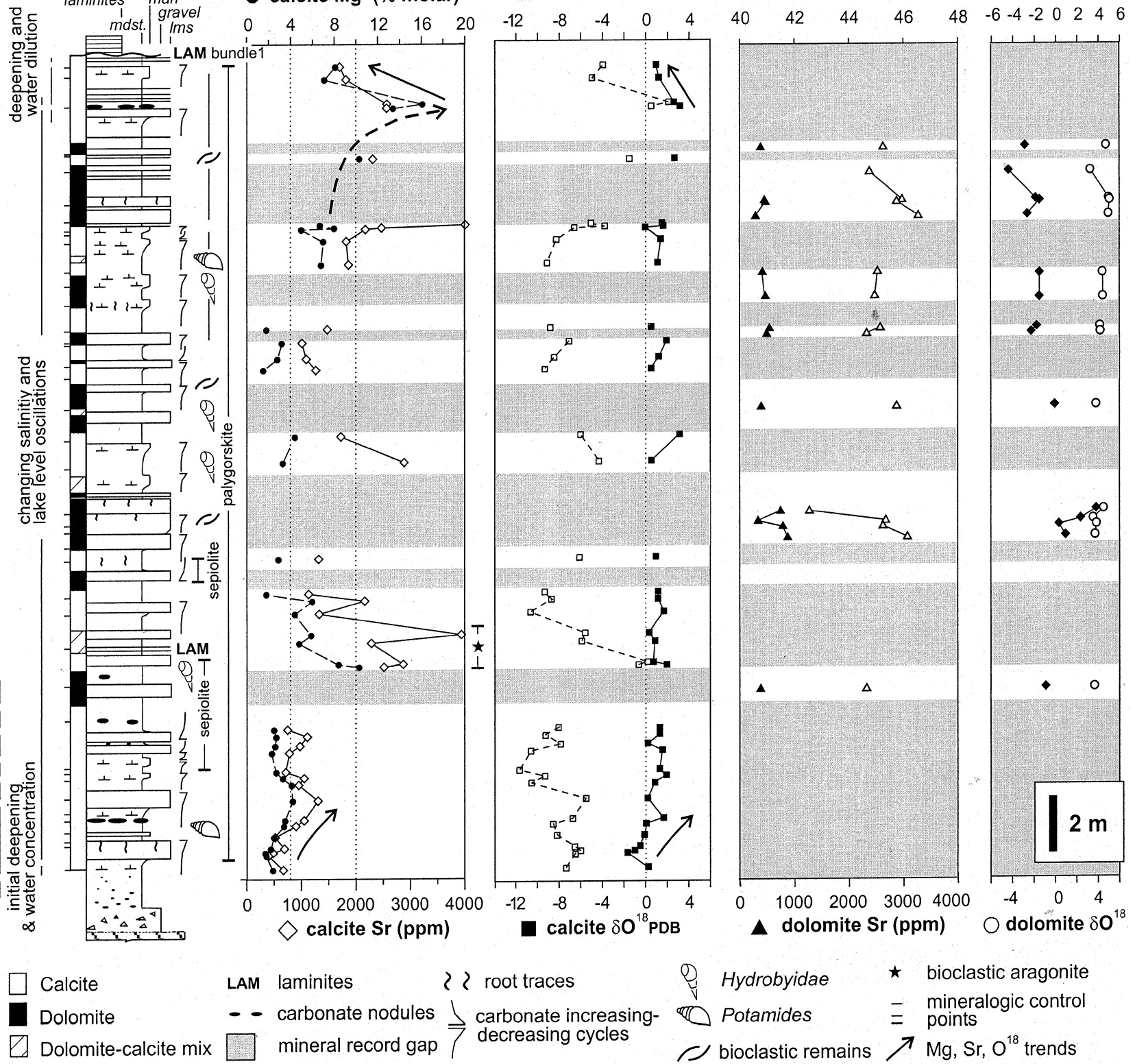

Fig. 5. Cyclically arranged palustrine-lacustrine mudstones and carbonates of Subunit $1 \mathrm{~A}$ in well 642 (see location in Figs 1 and 2). Note the distinct development of limestone and dolostone beds and the $\mathrm{Mg}, \mathrm{Sr}, \delta^{18} \mathrm{O}$ and $\delta^{13} \mathrm{C}$ trends. The truncated cycles record an upward-increasing carbonate content, which ends with a sharp transition into lacustrine clay-carbonate rhythmites and/or massive green mudstones belonging to the overlying cycle. These carbonate beds record intense pedogenesis, including vertical, clay-infilled root traces. Symmetrical cycles show more gradual transitions from the carbonate into the mudstone-dominated beds.

McKenzie, 1985; Arenas et al., 1997). Accordingly, mesoscopic pedogenic features observed in As Pontes dolostones suggest that dolomitization took place in porewaters resulting from hydrologic pumping and early pedogenesis. Dolomitization would have been favoured by the high $\mathrm{Mg}$ / Ca ratio, high alkalinity and low sulphate content in the porewaters (Cerling, 1996). Low Sr content in dolomite would have resulted from the 'puri- fication' (i.e. expulsion from lattice) of this cation during dolomitization (Land, 1985).

\section{Palaeoenvironmental interpretation}

The absence of widespread, well-developed lamination in these facies suggests complete bioturbation and deposition under oxic conditions. Some carbonate beds exhibit bioturbation and 


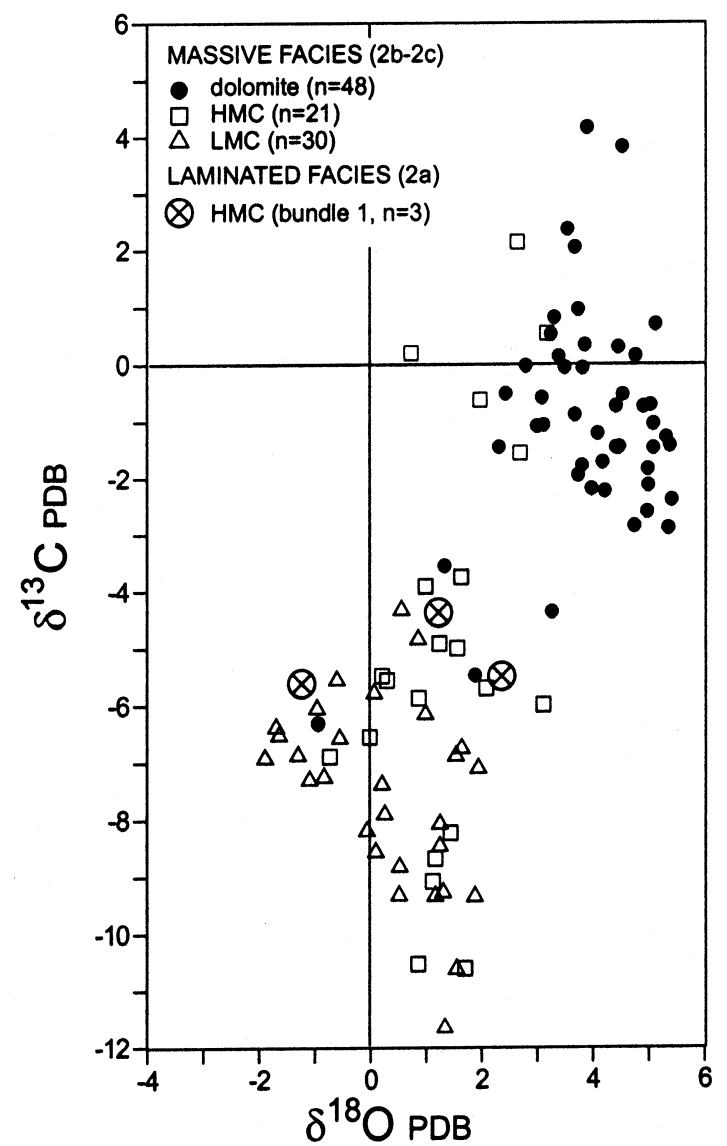

Fig. 6. $\delta^{18} \mathrm{O}$ and $\delta^{13} \mathrm{C}$ values of primary and early diagenetic carbonates in Subunit 1A (wells 642 and 5003). See text for further explanation and location of bundle 1 in Figs 5, 9 and 10.

traces of subaerial exposure, including root traces. These are typical pedogenic features and are consistent with a palustrine or marginal shallow lacustrine origin (Freytet \& Plaziat, 1982; Platt \& Wright, 1991).

The overall depositional, palaeobiological and early diagenetic features in this cyclical assemblage record repeated deepening-shallowing events linked to lacustrine expansion and contraction, which affected low-gradient, mostly marginal lacustrine ramps (Fig. 3a). The green, massive mudstones and marls correspond to bioturbated subaqueous lacustrine deposits, dominated by fine-grained contributions from the distal alluvial mudflats that fringed the lacustrine areas. These deposits record early water inflow and sediment input generating a shallow and persistent, holomictic water table. This water table could be fresh to dilute, but the frequent occurrence of monospecific Hydrobia accumulations and the saline water-adapted gastropod Potamides (Hyman, 1967; Anadón, 1989, 1992;
Plaziat, 1993) suggests that lacustrine waters quickly became saline (but not hypersaline). Moreover, the low organic matter preservation and the $\delta^{13} \mathrm{C}$-depleted values of the carbonate minerals suggest that these deposits formed under oxic bottom conditions and were affected by a subsequent anaerobic degradation of organic matter (via sulphate reduction) during shallow burial diagenesis.

The sporadic laminated beds of Facies 2a present in the cyclical assemblage of Subunit $1 \mathrm{~A}$ record the development of open offshore, relatively deep and/or sheltered lacustrine zones linked to rising and highstand water levels or deposition in protected shallow saline, stratified zones. The first interpretation is more probable given that the thicker laminated beds were often deposited in the deeper lacustrine zones, which developed close to the more rapidly subsiding, northern basin zones (Fig. 2a and b). Preservation of these deposits in shallower lacustrine zones was rather low, as evidenced by their contortion and disruption, caused by desiccation and bioturbation.

The wide extent of the palustrine carbonates and the restricted occurrence of finely stratified or laminated clay-carbonate facies attributed to deeper lacustrine deposits suggest that the bottom gradient was low and that the palustrine-lacustrine carbonate facies spread over the entire basin during water-level lowering. Nevertheless, at least during some high water level depositional episodes, the palustrine carbonates were deposited on marginal low-gradient ramps differentiated from the offshore lacustrine zones (Fig. 3a).

\section{OPEN OFFSHORE, DEEPER LACUSTRINE FACIES}

\section{Description}

\section{Facies $3 a$}

Fine-grained turbidites constitute centimetre- to decimetre-thick beds, most of which are made up of thinning-upwards, 2 to $40 \mathrm{~cm}$ thick bundles (Fig. 7a, Table 1). Some of the coarser beds include sand-sized vegetal debris (phytoclasts) and ostracod and gastropod bioclasts. This material was derived from underflows, which spread from distal alluvial fan zones and marginal vegetated lacustrine benches and reached the offshore zones (Figs 2a, b and 3b). Facies 3a occurs more frequently in the lower part of Subunit $1 \mathrm{~B}$, where it is interbedded with Facies 

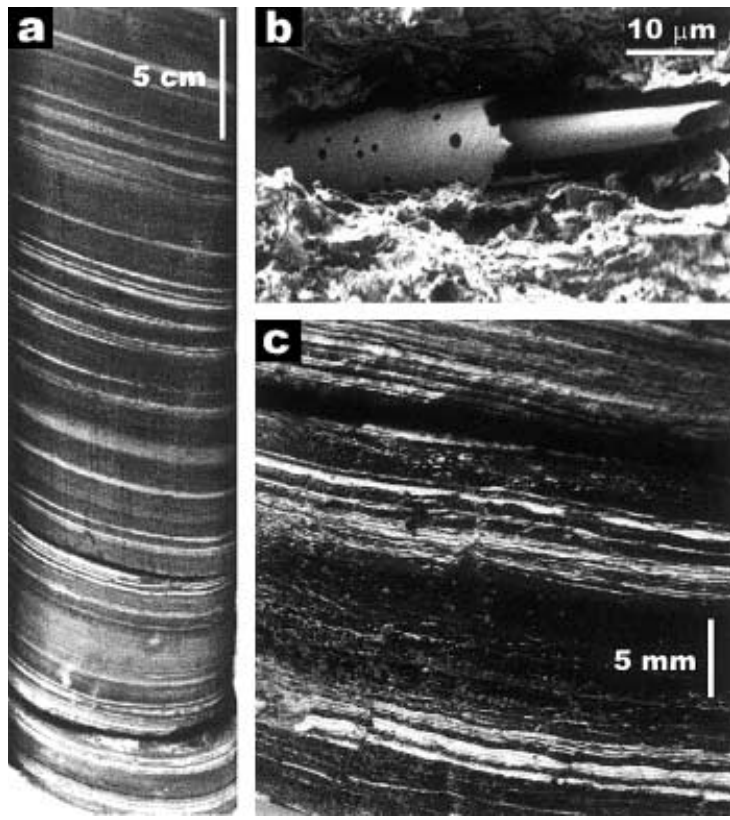

Fig. 7. (a) Open offshore, laminated lacustrine facies of Subunit 1B. Dark, fine-grained turbiditic beds (Facies 3a) alternate with lighter bundles of carbonate-clay rhythmites (Facies 3b). (b) Sponge spicule showing circular dissolution pits attributed to bacterial, fungal or diatom boring activity (bundle 15, Facies 3c). See text for explanation and references. (c) Close-up of clay-carbonate rhythmite bundles (bundles 11 and 12, Facies 3b). Note the changing laminae thickness and the syndepositional microfaults that affect the bundles. See text for further explanation.

$3 \mathrm{~b}$ and 3c deposits, and is better developed in the northern basin sequences.

\section{Facies $3 b$}

Thick, laterally continuous clay-carbonate, microlaminated varve-like couplets $(0.03-1.4 \mathrm{~mm}$ in thickness) are especially common in the lower part of Subunit 1B (Table 1). The thickest laminae bundles are oil shales (TOC 21-31\%) and can be traced basinwide. The carbonate laminae are grouped into centimetre-thick bundles (Fig. 7a-c) made up of $0 \cdot 1$ to $2 \mathrm{~mm}$ thick couplets and separated by thin (3a) turbidite beds. The clay laminae are dark and made up of detrital clay minerals plus sponge spicules, diatoms, ostracods and small gastropod remains; magnesiumrich clay minerals are absent. The carbonate laminae are whitish and chalky and show the predominance of inorganic, non-biogenic crystals and minor fauna and flora remains. Widespread corrosion of diatom frustules and sponge spicules and the replacement of diatom silica by LMC (Fig. 9) suggest relatively high $\mathrm{pH}$ conditions (Brookins, 1988). Moreover, early diagenetic pyrite and the circular dissolution structures recognized in the sponge spicules (Fig. 7b) record bioerosion, probably related to bacterial, fungal or diatom activity (as described by Andrejko et al., 1983 and Wuttke, 1992).

\section{Facies 3c}

This often occurs in the middle and upper part of Subunit 1B (Fig. 4). This facies differs from 3b in having thicker, less continuous carbonate laminae and widespread bioclastic laminae. Some pink laminae include significant amounts of early diagenetic siderite (Table 1).

\section{Carbonate fabric, mineralogy and $\mathrm{Mg}$ content}

As in similar cases studies (Hsü \& Kelts, 1978; Anadón et al., 1988) calcite (HMC, LMC) is the most widespread primary and early diagenetic carbonate mineral in the rhythmite facies. Crystals are polyhedral and heterometric, ranging from 7 to $10 \mu \mathrm{m}$ in size (Fig. 8).

Most of the carbonate laminae in Facies 3b and 3c consist of HMC, although two of the laminae bundles include LMC laminae (Fig. 9). HMC crystals
Fig. 8. Carbonate textures of laminated lacustrine facies of Subunit 1B. (a) SEM view of arrow-like HMC crystals (bundle 7, Facies 3b). (b) SEM view of clustered HMC crystals (bundle 3, Facies 3b). (c) SEM view of rhombohedral HMC crystals showing dissolution textures (bundle 14, Facies 3 c).
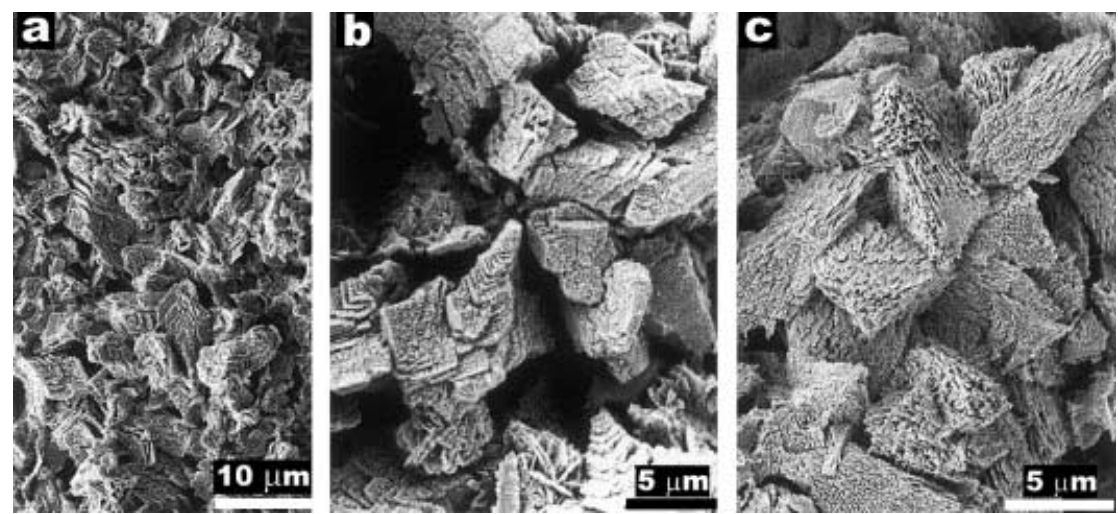

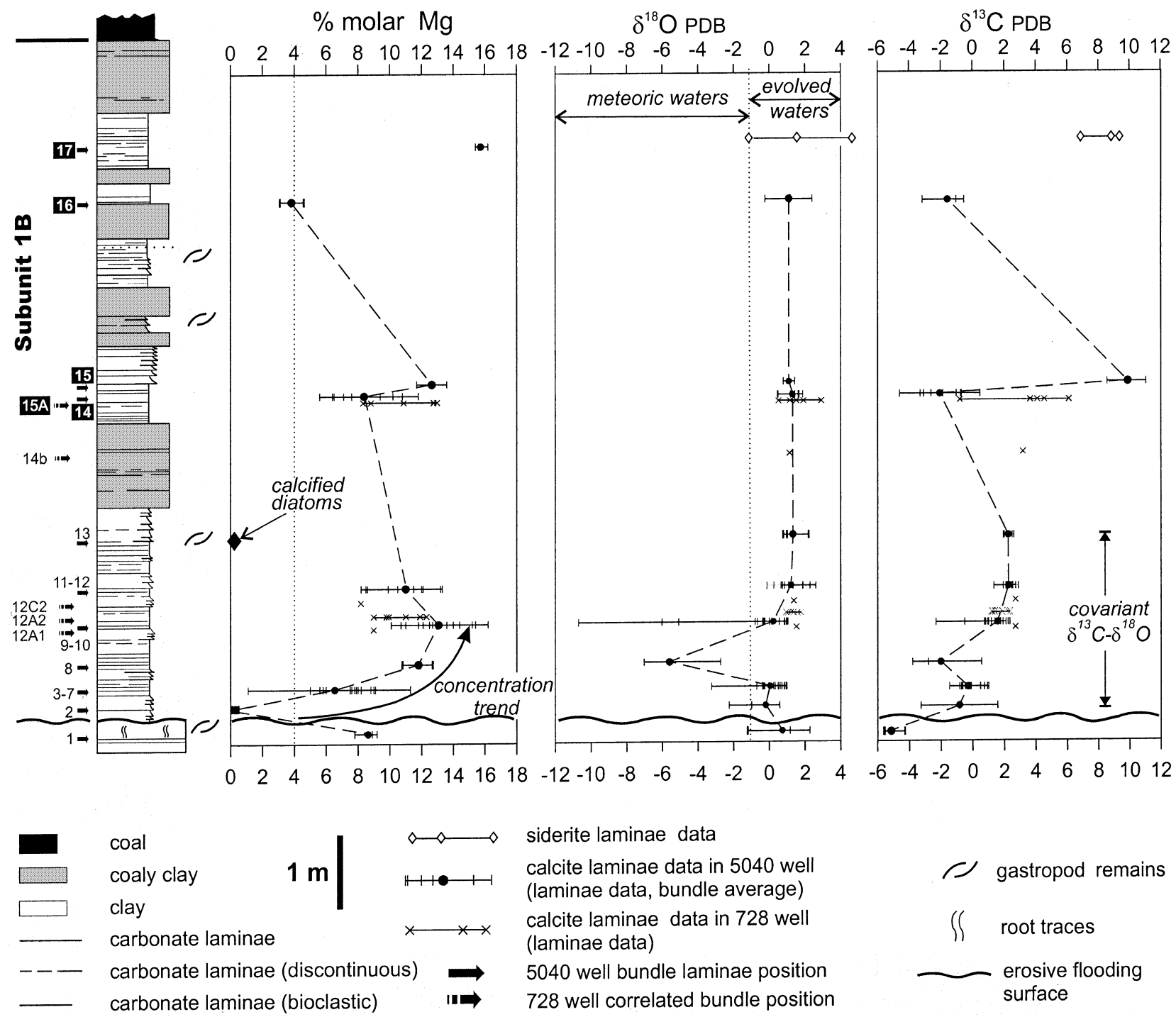

Fig. 9. $\mathrm{Mg}, \delta^{18} \mathrm{O}$ and $\delta^{13} \mathrm{C}$ profiles of the HMC, LMC and siderite from the carbonate-clay rhythmites in Subunit 1B (correlated wells 642 and 728 ). The average $\mathrm{mol} \% \mathrm{Mg}$ in the bundles displays a trend that suggests increasing salinity. The $\delta^{18} \mathrm{O}$ values show a clear shift to positive values, punctuated by dilution episodes with lighter $\delta^{18} \mathrm{O}$ (bundles 2-10). The $\delta^{18} \mathrm{O}$ and $\delta^{13} \mathrm{C}$ values show a clear covariant trend in the lower part of the subunit (bundles 2-10) pointing to closed hydrological conditions. Bundle 1, Facies 2a. Bundles 2-14b, Facies 3b. Bundles 14-17 (black squares), Facies 3c.

show rhombohedral shapes (Fig. 8c), and some display an arrow-like morphology (Fig. 8a and b). In some cases, crystal faces are either corroded or show additional growth (Fig. 8c). Siderite crystals in these facies are rhombohedral, 1-2 $\mu \mathrm{m}$ in size, with well-preserved crystal faces. They occur as clusters with a similar crystal orientation and infill intercrystalline calcite porosity.

The Mg content in the LMC ranges from $0 \cdot 1$ to $3.8 \mathrm{~mol} \%$, whereas in the HMC, it ranges between 4.6 and $16.2 \mathrm{~mol} \%$. The average $\mathrm{Mg}$ content of the calcites in each clay-carbonate laminae bundle in well 642 increases upwards in the lower part of
Subunit 1B (Fig. 9). Moreover, most of the bundles show clear increasing \% Mg trends, which are arranged in pluriannual cycles. These trends in $\mathrm{Mg}$ increase do not correlate significantly with the lamina thickness or with the oxygen and carbon isotopic changes described below (Fig. 10).

\section{Oxygen and carbon isotopic results}

The $\delta^{18} \mathrm{O}$ values of most of the carbonate laminae in Facies $3 \mathrm{~b}$ range from -1 to $+2 \cdot 6 \%$, but a few laminae have lower values (Fig. 11b). The $\delta^{13} \mathrm{C}$ values are between -4 and $+3 \%$. Covariance 

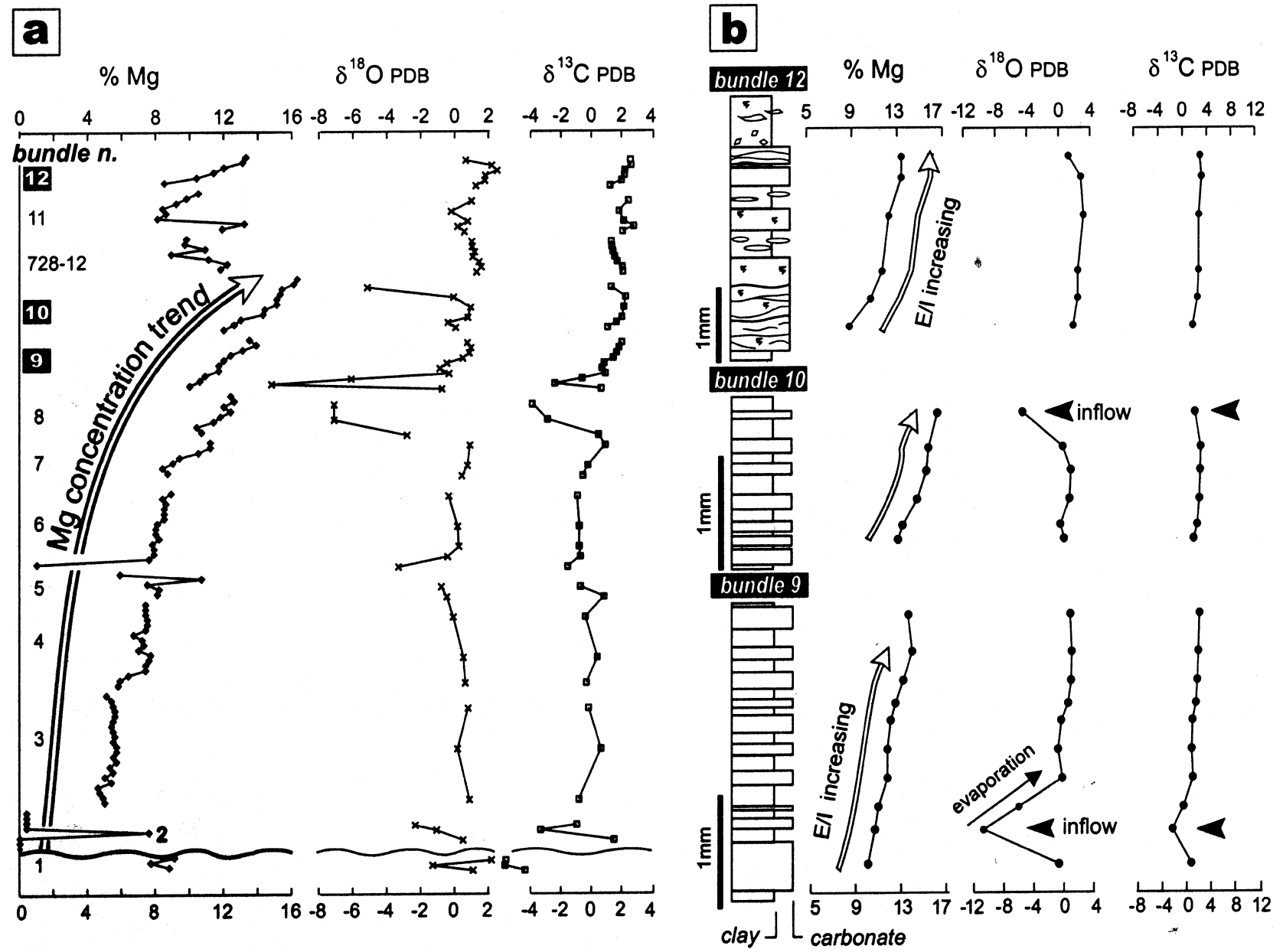

Fig. 10. (a) Succession (not to scale) of the clay-carbonate rhythmite bundles 1-12 from the lower part of Subunit $1 \mathrm{~B}$, showing $\mathrm{Mg}, \delta^{18} \mathrm{O}$ and $\delta^{13} \mathrm{C}$ of the primary carbonates (see Fig. 9 for stratigraphic location of the bundles). (b) The same trends are shown in detailed sedimentological logs of some selected rhythmite bundles (9, 10 and 12). The trends of increasing Mg content record pluriannual to several thousand-year-long cycles of increasing solute concentration. The lighter $\delta^{18} \mathrm{O}$ values point to significant dilution episodes caused by major water inflows.

between $\delta^{13} \mathrm{C}$ and $\delta^{18} \mathrm{O}$ is high. Calcite in the thicker Facies 3c laminae show slightly changing $\delta^{18} \mathrm{O}$ values (average $+0 \cdot 7 \%$; Figs 9 and 11a). The $\delta^{13} \mathrm{C}$ values are clearly more variable than in Facies 3b. Some of the bundles display low $\delta^{13} \mathrm{C}$ values (between -3 and $+11 \%$ ). No clear sequential trends can be recognized in these changes. Finally, $\delta^{18} \mathrm{O}$ and $\delta^{13} \mathrm{C}$ do not show covariance, and $\delta^{18} \mathrm{O}$ and the \% $\mathrm{Mg}$ do not correlate.

\section{Palaeoenvironmental interpretation}

The open, offshore lacustrine assemblage facies was deposited initially at a maximum depth ranging from 10 to $15 \mathrm{~m}$, although this depth decreased as the basin infill progressed (Fig. 3b). This assemblage is regarded as deep, as opposed to the aforementioned shallow-dominated facies assemblage. Maximum depth estimation was established on the basis of: (1) the thickness of the laminated lacustrine basin infill episode; and (2) the height of gentle progradational marginal clinoforms observed in the stratigraphic panels (Fig. 2c; Cabrera et al., 1995; Ferrús, 1998).

The widespread occurrence of laminated facies and the good organic matter preservation show that the water body was perennial and sufficiently deep to allow long periods of water stratification (meromixis). The carbonate-clay rhythmite intervals record repeated limnological changes, which led to alternating deposition from: (1) carbonate precipitation from warm surface waters; and (2) suspensions of clay biogenic clasts and organic matter. The microlaminated clay-carbonate couplets of Facies $3 \mathrm{~b}$ are consistent with brief, highfrequency climatic rhythms, probably seasonal, although conclusive evidence of such periodicity is not available. The grouping of the clay-carbonate 


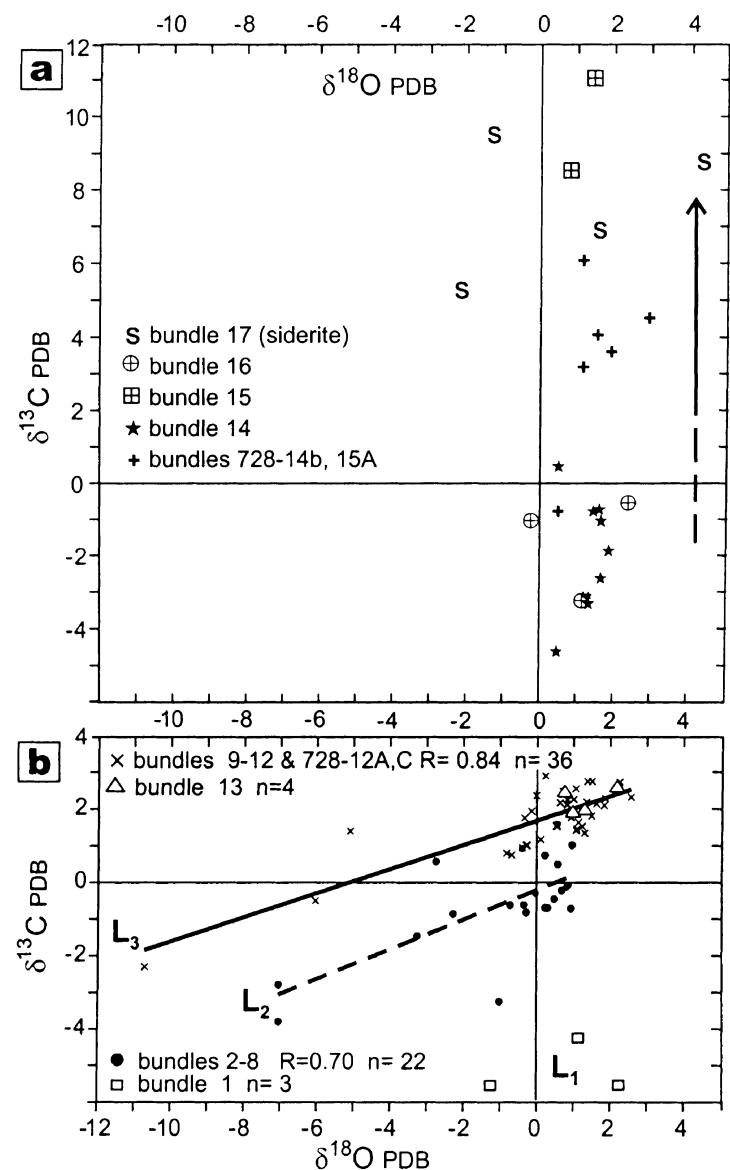

Fig. 11. $\delta^{13} \mathrm{C}$ and $\delta^{18} \mathrm{O}$ of the carbonate laminae from Subunit 1B (wells 5040 and 728). (a) Arrow indicates positive shifts in the $\delta^{13} \mathrm{C}$ values recorded in siderite and some HMC laminae from the upper part of the subunit, which suggests a methanogenic influence. (b) The covariant trends (labelled $\mathrm{L}_{1}, \mathrm{~L}_{2}$ and $\mathrm{L}_{3}$ ) recorded in the lower part of the subunit point to closed hydrological conditions.

couplets in bundles and their alternation with turbidites suggest successive pluriannual to centennial periods of changing hydrochemistry and fine-grained sediment inputs. These changes could be related to a variety of factors, either regional (i.e. changing rainfall and vegetation cover) or local (i.e. shifting of terrigenous contributions from the alluvial zones).

\section{EVOLUTION OF THE LACUSTRINE SYSTEM}

\section{Basin fill evolution and lacustrine-palustrine carbonate mineralogy}

The eastern As Pontes sub-basin fill sequence records an early period of basin formation with related scree and alluvial deposits. This was followed by the development of palustrine to shallow lacustrine terrigenous sedimentation (Table 1, Fig. 5) These palustrine-dominated environments evolved into a more diverse framework, in which terrigenous carbonate cyclical facies were deposited. Areally extensive and relatively deep, open offshore lacustrine zones developed during this stage, but they often shrank, and shallow lacustrine and palustrine ramps spread over most of the basin. This resulted in low generation and poor preservation of organic-rich and laminated facies.

The sedimentological, mineralogical and palaeobiological records in the lower subunit demonstrate that the water depth and salinity were highly variable, characterizing closed lacustrine conditions. The possible occurrence of primary aragonite and the widespread early diagenetic dolomite indicate that the $\mathrm{Mg} / \mathrm{Ca}$ ratio attained relatively high values. This high $\mathrm{Mg} / \mathrm{Ca}$ ratio resulted from the $\mathrm{Mg}$ contribution from the weathering of metamorphic rocks containing $\mathrm{Mg}$ silicates. The removal of Ca during the early stages of lacustrine evolution (corresponding to the deposition of LMC and HMC in the lower lacustrine cycles) contributed to the relatively high $\mathrm{Mg} / \mathrm{Ca}$ ratios, which remained high despite the generation of Mg-rich clays (i.e. palygorskite and sepiolite). Moreover, the fact that the most significant dolomite accumulations are linked to pedogenic palustrine facies suggests that the $\mathrm{Mg}$ / Ca ratio increased as a result of evaporitic pumping. Neither dolomite (early diagenetic or primary) nor aragonite is indicative of a saline lake formed under evaporative conditions (Müller \& Wagner, 1978). Nevertheless, in As Pontes, high oligosaline to mesosaline and even eusaline conditions are confirmed by the athalassic faunal record.

The palustrine-lacustrine, ramp-dominated depositional framework of Subunit 1A was replaced by a deeper, meromictic and more complex lacustrine framework, ranging from relatively uniform deeper lacustrine environments (with fine-grained turbidites and claycarbonate couplets) to marginal bench-talus environments (Subunit 1B). Primary HMC was the dominant carbonate phase in the open offshore lacustrine deposits during this evolutionary stage, whereas LMC and siderite were the most common early diagenetic carbonates.

The occurrence of primary LMC in the lowermost clay-carbonate bundles suggests that the $\mathrm{Mg} / \mathrm{Ca}$ ratio fell during major flooding events. This ratio increased during the successive depo- 
sitional stages, to remain relatively high. The changes in primary carbonate mineralogy (i.e. from LMC to HMC) reflect the early precipitation of Ca-carbonates (mostly LMC), which caused Ca removal from the lake waters and led to periods of relatively higher $\mathrm{Mg} / \mathrm{Ca}$ waters, owing to the more conservative character of $\mathrm{Mg}$ and the hydrologically closed conditions (Müller \& Wagner, 1978; Wetzel, 1983). The absence of primary aragonite and the occurrence of fossil frogs and typical fresh to slightly oligosaline water snails (Lymnaea, Planorbis) suggest that the $\mathrm{Mg} / \mathrm{Ca}$ ratio and salinity never attained very high values.

Swamp environments also developed in the marginal lacustrine zones and prograded basinward, resulting in the generation of several progradational-retrogradational sequences, which punctuated the basin infill evolution. The upper part of the basin infill sequence records the late basinward progradational infilling of the offshore lacustrine zones by encroachment of the marginal swamps. This stage was characterized by increasing higher plant contributions to the subaqueous lacustrine zones, which underwent a gradual decrease in areal extent and water volume.

\section{Carbonate isotopic evolution}

\section{Cyclically arranged palustrine-lacustrine assemblage}

Primary HMC was recognized in the scarce, deeper lacustrine clay-carbonate couplets recorded in the lower Subunit 1A, the only primary carbonate phase recorded there. Some of the LMC and HMC that cluster close to the isotopic values of the primary HMC might also be primary, but no evidence is available. Thus, it is assumed that fine-grained LMC, HMC and dolomite are the earliest diagenetic carbonate minerals in the massive lacustrine-palustrine sequences in Subunit 1A (Fig. 5).

Dolomite is enriched in ${ }^{18} \mathrm{O}$ in relation to calcite by between +1 and $+7 \%$ (Clayton et al., 1968; Fontes et al., 1970; Land, 1985). These dolomite ${ }^{18} \mathrm{O}$ values are consistent with precipitation from similarly evolved lacustrine waters (Craig \& Gordon, 1965). Approximately onequarter of the LMC samples cluster with negative $\delta^{18} \mathrm{O}$ values (i.e. from -2 to 0 ), suggesting that either the evolution of the lacustrine porewaters was not so pronounced or the input of ${ }^{16} \mathrm{O}$-rich meteoric waters was higher, compared with the higher HMC and dolomite $\delta^{18} \mathrm{O}$ values. Some of the lowest LMC $\delta^{18} \mathrm{O}$ values occur in the lower- most cyclical sequences in Subunit 1A, suggesting less concentrated water conditions in the basin (Fig. 5).

The very wide range (i.e. $16 \%$ ) of $\delta^{13} \mathrm{C}$ values could represent early diagenetic precipitation of carbonates under varying mixtures of atmospheric and soil-derived $\mathrm{CO}_{2}$ from the surrounding emerged zones. With regard to $\delta^{13} \mathrm{C}$ variations, a number of authors have demonstrated that groundwaters in well-vegetated catchment areas with well-developed soils are more influenced by the decomposition of isotopically light plant material and have $\mathrm{CO}_{2}$ with negative $\delta^{13} \mathrm{C}$ values (Talbot, 1990). Moreover, changes in the vegetative cover in the source and depositional palustrine areas could subordinately account for these variations. Thus, a decrease in C4 plant contributions $\left(\delta^{13} \mathrm{C},-12\right.$ to $\left.-14 \%\right)$ and a correlative increase in $\mathrm{C} 3$ plant contributions $\left(\delta^{13} \mathrm{C},-25\right.$ to $-28 \%$ ) would cause a $\delta^{13} \mathrm{C}$ decrease and vice versa. Some of the changes in the $\delta^{13} \mathrm{C}$ DIC (dissolved in organic carbon) in the resident waters could also have been controlled by variable recycling of organic matter, which was modified by burial rate. On the other hand, the lower $\delta^{13} \mathrm{C}$ values of LMC and HMC, ranging from -7 to $-12 \%$, would mainly be related to early diagenetic precipitation of calcite in association with bacterial sulphate reduction, because such low values do not usually result from atmospheric or soil-derived $\mathrm{CO}_{2}$ contributions (Talbot $\&$ Kelts, 1990).

\section{Open offshore deeper lacustrine assemblage}

In the As Pontes deeper lacustrine sequences, the $\delta^{18} \mathrm{O}$ values from primary HMC are associated with the hydrological balance in the lake, which depends on the evaporation/inputs ratio. In general, an increase in $\delta^{18} \mathrm{O}$ values in primary carbonates reflects increasing evaporation or longer water residence times in the lake. Therefore, the primary calcites with positive or strongly positive $\delta^{18} \mathrm{O}$ values could represent sedimentation during relatively concentrated, longer residence time stages. The $\delta^{18} \mathrm{O}$ and $\delta^{13} \mathrm{C}$ values of the primary carbonates in the lower bundles (2-12 in Figs 9 and 10) show covariant trends (L2 and L3 in Fig. 11b) and suggest that the lacustrine system was hydrologically closed. The covariant trends have a relatively gentle intermediate slope, suggesting that the area/ depth ratio of the basin during the sedimentation of these deposits was high. This accords well with the shallowness of the basin (i.e. from a 
maximum of $10-15 \mathrm{~m}$ to a few metres), established on the basis of depositional and geometric constraints.

The low to very low $\delta^{18} \mathrm{O}$ values (between $-3 \cdot 2$ and $-10 \cdot 7 \%$ ), recorded in some of the LMC included in the covariant trend of Subunit 1B suggest that calcite precipitation occurred during short dilution periods owing to a greater influx of isotopically lighter waters. These low $\delta^{18} \mathrm{O}$ values should be regarded as being representative of the mean oxygen isotopic composition of the inflow, which reflects the composition of the catchment precipitation.

The inflow responsible for reducing $\delta^{13} \mathrm{C}$ and $\delta^{18} \mathrm{O}$ (up to 7 and $13 \%$ o respectively) would be related to large surface run-off and/or underground recharge events linked to exceptional rainfall in the region. The differences in the amount of isotopic lowering between $\delta^{13} \mathrm{C}$ and $\delta^{18} \mathrm{O}$ would result from the fact that $\delta^{18} \mathrm{O}$ in the lacustrine waters decreases following a linear trend, whereas $\delta^{13} \mathrm{C}$ is especially influenced by the $\mathrm{CO}_{2}$ isotopic composition of the lacustrine resident waters ( $\mathrm{Li} \& \mathrm{Ku}, 1997)$. The significance of these major flood events would be enhanced by the relatively small lacustrine water reservoir volume and by water stratification, which would have resulted in the generation of widespread meteoric water plumes in the epilimnion during the flood events (Johnson et al., 1991).

Isotopically light laminae in the lower part of Subunit 1B are scarce compared with the isotopically heavy laminae. Most of the carbonate laminae in the L2 and L3 covariant trends show high $\delta^{18} \mathrm{O}$ and $\delta^{13} \mathrm{C}$ values with little variation (Fig. 11b). Thus, the lacustrine system was characterized during most of its evolution by an isotopically heavy, gently varying water body, close to steady state (Sofer \& Gat, 1975; Lister et al., 1991) and only punctuated by sharp excursions to light isotopic values. Shorter term (annual to pluriannual) $\delta^{18} \mathrm{O}$ changes (about $2 \%$ ) recorded in most of the clay-carbonate laminae bundles could be attributed to a variety of mechanisms (mixing of minor, varying meteoric water inputs, changes in evaporation rates, water temperature changes, organic productivity changes).

The differences between the $\delta^{13} \mathrm{C}$ values in the covariant trends L2 and L3 (about 3\%o could be caused by (Bein, 1986; Talbot, 1990; Valero-Garcés et al., 1997; Wachniew \& Rozanski, 1997): (1) the inflow and mixing of variable amounts of meteoric water with isotopically light ${ }^{12} \mathrm{C}$ contributions; (2) changes in $\delta^{13} \mathrm{C}$ in the incoming waters due to vegetation changes in the source areas around the lacustrine zones; (3) the different temperatures in the epilimnion (probably less relevant); and (4) variations in biological productivity during a basically stratified lake period on the assumption that most of the carbonates precipitated in the epilimnion. It is not possible to assess the importance of each of these processes, which probably acted simultaneously. It has been suggested that changes in primary productivity have little impact on the composition of the lake DIC of longresidence water bodies (Turner et al., 1983; Talbot \& Kelts, 1990; Utrilla et al., 1998), although this is debatable. An alternative interpretation for the heavier $\delta^{13} \mathrm{C}$ values is changing rates of net $\mathrm{CO}_{2}$ outgassing from the lake to the atmosphere (a common process in most recent lakes; Cole et al., 1994). This outgassing would account for the heavier $\delta^{13} \mathrm{C}$ values, which could be attained under closed, long-residence water conditions. Varying organic matter production and recycling through oxidation would also account for the observed $\delta^{13} \mathrm{C}$ variations.

The $\delta^{18} \mathrm{O}$ values of the diagenetic LMC, which replaced diatom frustules (bundle 13, Figs 9 and 11b), cluster between those of the primary LMC and HMC that precipitated from evolved lacustrine waters. This suggests that replacement of silica took place in these evolved waters rather than in meteoric waters. The same explanation can be stated for siderite $\delta^{18} \mathrm{O}$ values, although they show a slightly larger range. In contrast, the $\delta^{13} \mathrm{C}$ values for early diagenetic LMC and siderite are rather diverse, with siderite reaching significantly higher values (bundle 17, Figs 9 and 11a). In many recent lacustrine basins, ${ }^{13} \mathrm{C}$ enrichment in early diagenetic carbonates is related to bacterial methanogenesis (Talbot, 1990). The siderite precipitation in the uppermost laminite bundles in upper Subunit 1B was probably related to this process (Berner, 1981; Mozley \& Wersin, 1992), which in turn was enhanced by increasing contributions of vegetal debris and eutrophization of the lake. Moreover, given the shift towards higher $\delta^{13} \mathrm{C}$ values of some of the HMC in the upper bundles, it cannot be ruled out that partial early diagenetic HMC precipitation could take place under the influence of methanogenic $\mathrm{CO}_{2}$.

\section{Integration of the isotope data from lower and upper subunits}

The primary HMC from the lower subunit laminites has $\delta^{18} \mathrm{O}$ values in the same range as the higher values in the upper subunit (Fig. 12). Low $\delta^{18} \mathrm{O}$ values related to dilution episodes are not 
Fig. 12. Integrative sketch of $\delta^{18} \mathrm{O}$ and $\delta^{13} \mathrm{C}$ values of all primary and early diagenetic carbonate samples from lacustrine Subunits $1 \mathrm{~A}$ and $1 \mathrm{~B}$ in the eastern As Pontes subbasin. The reference sedimentological log on the left is not to scale. The main processes affecting the primary and diagenetic trends are indicated. Note the location of the carbonate samples (D, L, M) represented by the clusters in the synthetic log. D, dolomite; L, laminites; M, massive carbonate mudstones. Arrows between cluster L1 and covariant trends L2 and L3 suggest the positive $\delta^{13} \mathrm{C}$ trend in successive evolutionary stages. See discussion in the text.

recorded in this subunit, but this could be a bias caused by the small number of clay-carbonate couplets available for sampling and by the rapid shift to the higher isotope values. Consequently, only the $\delta^{18} \mathrm{O}$ heavier stages are identified in this isotopic record. During the sedimentation of both lower and upper subunits, meteoric waters apparently evolved very rapidly from lower to higher isotopic values.

Most of the dolomite $\delta^{18} \mathrm{O}$ and $\delta^{13} \mathrm{C}$ values cluster above the range of most of the early diagenetic HMC and LMC (Fig. 12). Nevertheless, these values also scatter close to the end of the covariant trends in the upper subunit and also close to the cluster of primary HMC in the lower subunit. This suggests that the waters from which dolomite precipitated in lower Subunit 1A could have had $\delta^{18} \mathrm{O}$ values similar to those of the evolved waters recorded in upper subunit $1 \mathrm{~B}$. This means that the residence times and/or evaporation rates remained similar throughout the evolution of the lacustrine system.

\section{Changes in basin hydrology}

\section{Lacustrine establishment and early salinity increase}

The lower Subunit 1A represents the onset of a well-developed palustrine- to shallow lacustrinedominated environment (Fig. 2), in which fine-

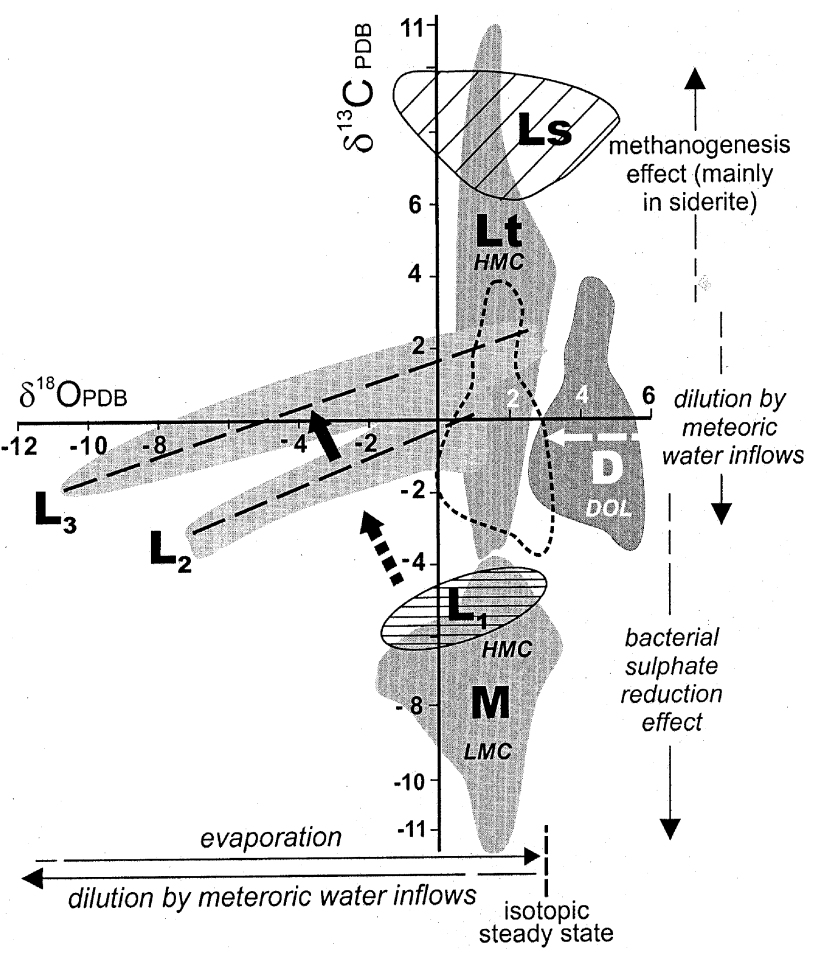

grained mudstones and palustrine (LMC-dominated) limestones were deposited. The $\mathrm{Mg}$ and $\mathrm{Sr}$ content changes point to variable solute composition, whereas the relatively high and roughly upward increase in $\delta^{18} \mathrm{O}$ values suggests high evaporation and/or residence time.

\section{Changing solute trends}

A subsequent rise in the $\mathrm{Mg} / \mathrm{Ca}$ ratio, probably related to a salinity increase, resulted in widespread primary and early diagenetic HMC precipitation and in dolomite and Mg-rich clay generation. The lacustrine waters probably attained mesosaline to eusaline conditions, favouring the development of a thalassoid fauna. The mudstone-carbonate cycles record higher frequency water level oscillations, probably linked to salinity changes. Salinity maxima in the remaining water bodies could be coeval with the maximum spreading of the palustrine environments in which dolomitization took place (Facies 2c). Salinity minima could be coeval with a rise in the water level and with the deposition of open offshore lacustrine carbonate-clay couplets (Facies 2a) and carbonate-rich mudstones (Facies 2b).

\section{Salinity decrease trend and system dilution}

A deepening and freshening of the system during the deposition of the upper part of Subunit $1 \mathrm{~A}$ is 
suggested by the occurrence of laminated claycarbonate couplets and by the decreasing $\mathrm{Mg}$ content and $\delta^{18} \mathrm{O}$ values of the limestones. These changes heralded a dilution and deepening event, which culminated in the deposition of the lowermost portion of Subunit 1B.

\section{Meromictic lake: freshwater-oligosaline conditions and final basin infill}

The water balance of the lake changed in the transition from Subunit $1 \mathrm{~A}$ to the overlying Subunit 1B. Increasing water inflow resulted in falling salinity, as evidenced by the absence of thalassoid gastropods, which were replaced by freshwater species, together with the occurrence of fossil frogs which were poorly adapted to highly saline conditions. Moreover, HMC (primary and perhaps in part early diagenetic), LMC (primary and early diagenetic) and siderite (early diagenetic) are the main carbonates present. This mineralogy reflects variations in the $\mathrm{Mg} / \mathrm{Ca}$ ratio and oscillations of the solute composition, which were not as important as in the underlying unit.

The lower part of Subunit 1B records a more expanded lacustrine framework, with an early major flooding that resulted in a significant water volume increase and basin deepening and freshening (Fig. 2). The meromictic or oligomictic conditions invoked to account for the laminated lacustrine facies could be enhanced by the tropical-subtropical climate proposed for NW Spain during the Oligocene on the basis of the available palaeobotanical data. Stratification of the waters could have been reinforced initially by the superposition of the incoming meteoric flood waters on the pre-existing, more saline water body during the preceding lacustrine stage (ectogenic meromixis).

The Mg increase in the lower part of Subunit 1B suggests an early water concentration up to oligosaline conditions. The increasing Mg content in successive carbonate laminae bundles suggests progressive increase in the evaporation/water input (E/I) ratio, which reflects distinct seasonal to pluriannual cycles (Fig. 10). Moreover, the wide scatter in $\delta^{18} \mathrm{O}$ values and the prevailing closed basin conditions indicate that the As Pontes lake was especially sensitive to changes in the evaporation/inflow ratio.

The poorer preservation of the geochemical and mineralogical record in the upper part of Subunit 1B prevents us from tracing its detailed evolution, although the scarce data suggest that further oscillations and solute composition changes took place before the final sedimentary infilling by progradation of the marginal parts of the system.

In intermediate to long time ranges, the $\mathrm{Mg}$ concentration trend in Subunit 1B records several stages of increase and decrease, from the early lacustrine flooding to a first maximum that was followed by a pulsating evolution (see lower bundle succession in Subunit 1B; Figs 9 and 10). Note that the average salinity trends marked by the Mg increase are not always coeval with the increasing residence time or E/I ratio, evidenced by the $\delta^{18} \mathrm{O}$ increase. At shorter time intervals (pluriannual to centennial), positive or negative shifts in $\delta^{18} \mathrm{O}$ (i.e. increasing or decreasing E/I) do not usually parallel changes in the $\mathrm{Mg}$ content. Because the $\mathrm{Mg}$ concentration tends to be very conservative on a short time scale (Wetzel, 1983), this would account for the frequent absence of short-term correlation between $\mathrm{Mg}$ and $\delta^{18} \mathrm{O}$ trends (Fig. 10).

The $\delta^{18} \mathrm{O}$ and $\mathrm{Mg}$ content changes recognized in the primary carbonates of the bundle laminae record minor, very short-term hydrochemical changes in the system. These changes could take place over time spans ranging from pluriannualdecennial periods up to several thousand years (Figs 9 and 10) and may be in relation to cyclical precipitation shifts.

\section{Infill organization and controlling factors in basin evolution}

A major trend of water input increase and lake level rise is clearly recorded by the superposition of Subunits 1A and 1B, linked to the change from shallow, saline lacustrine conditions to deeper, freshwater conditions, which persisted until the lake's final infilling. This change caused the loworder stratigraphic arrangement of the up to $100 \mathrm{~m}$ lacustrine infill (Fig. 13, curve 1). Apart from this low-order, deepening trend, dm- to m-thick cyclical sequences also occur in Subunits 1A and 1B. These high-order sequences (Fig. 13, curve 2) resulted from alternating lacustrine flooding and shrinkage episodes, related to changing water input/output ratios in the system. The magnetostratigraphic dating of the lacustrine infill (Huerta et al., 1997; Ferrús, 1998) suggests that the deposition of the whole low-order sequence lasted around $1.5 \mathrm{My}$ and that the periodicity orders of the dm- to m-thick cycles would be close to an average of $30 \mathrm{ky}$. The thinnest rhythmic clay-carbonate microlaminations (a few micrometres to a few millimetres thick) resulted from very short-term, probably seasonal changes, 


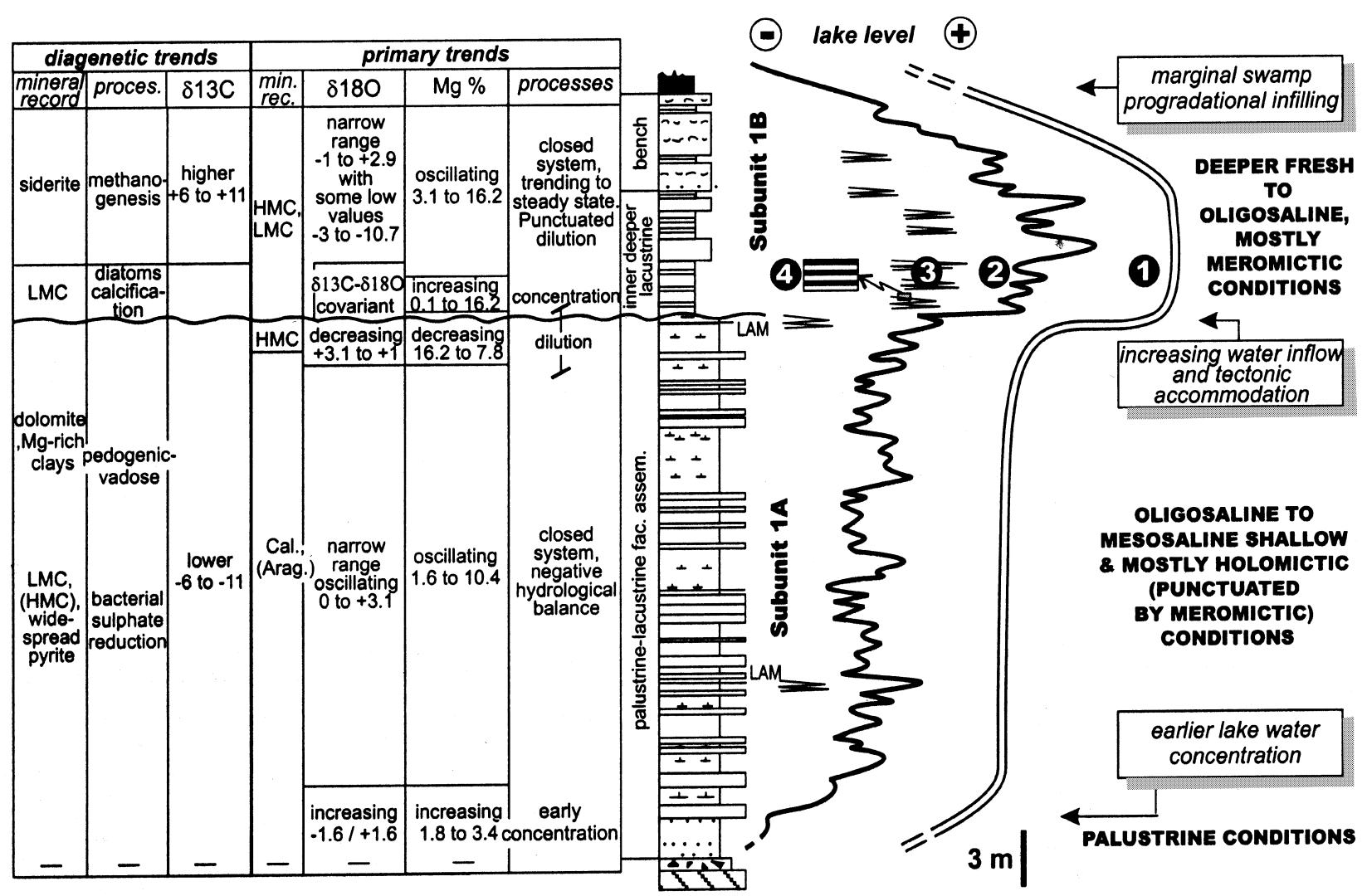

Fig. 13. Evolution of the lacustrine record in the As Pontes Basin. The major tectonic and hydrological changes are indicated. Curve 1, low-order lacustrine basin infill sequence that was controlled by tectonics and the headward spread of the catchment drainage. Curve 2, cyclically arranged mudstones and carbonates (Subunit 1A) and interbedded turbidite beds, rhythmite bundles and marginal bench facies (Subunit 1B), which were mainly controlled by climatic oscillations. Curve 3, decennial to millennial carbonate-clay rhythmic bundles. Number 4 indicates probable seasonal clay-carbonate couplets. See text for further explanation.

whereas the carbonate-clay rhythmic bundles would develop during decennial to millennial time spans (Fig. 13, curves 3 and 4).

The stratigraphic arrangement of the lacustrine As Pontes Basin records the long-term (i.e. $1.5 \mathrm{My}$ ) trend of expansion, deepening and infilling of a lake and the repeated, short-term (i.e. around $30 \mathrm{ky}$ on average) water level oscillations that were superimposed on this trend. The causes of these water balance changes can be constrained by taking into account the palaeotectonic, palaeogeographic and palaeoclimatic setting of the basin. Thus, the low-order sequence transition from Subunit 1A to Subunit 1B was related to a water volume increase from about $1 \mathrm{hm}^{3}$ in the earliest evolutionary stages to $11.5 \mathrm{hm}^{3}$ in the maximum lacustrine spreading and deepening stage (Fig. 2a' and $b^{\prime}$ ). There is no palaeobotanical evidence for significant climatic forcing (i.e. a rainfall increase) during the transition from $1 \mathrm{~A}$ to 1B (Baltuille et al., 1992). Therefore, this water volume increase must have been caused by the coupled influence of: (1) the increment of accommodation in the basin caused by increasing subsidence rate related to the synchronous activity of reverse and normal faults in the strike-slip fault system, which outstripped sedimentation rates (Ferrús, 1998); and (2) the enlargement of the catchment of the As Pontes eastern subbasin (Barsó et al., 2000). Owing to its location on the uplifted zones of the strike-slip system, tectonics could have influenced drainage evolution in the catchment area, but simple headward extension of the drainage network can also account for the reported catchment enlargement.

The warm subtropical climatic regime in NW Spain and its palaeolatitudinal position during the Oligocene made this region very sensitive to high-frequency cyclical palaeoclimatic variations (i.e. from dry to moister conditions). This influence was significant in terms of water and sediment contributions, palaeohydrochemistry and water stratification. The changes in these parameters would have resulted in the cyclical 
dm- to m-thick sequences in both subunits (curve 2, Fig. 13) and mainly record this climatic forcing on the lacustrine system. The limited total thickness of these cyclical sequences precludes the definitive statistical testing of their periodicity and their possible attribution to orbitally forced periodical cycles (Berger \& Loutre, 1994). Nevertheless, their range of thickness and estimated average duration (i.e. $30 \mathrm{ky}$ ) are similar to that observed in other lacustrine sequences that have been interpreted as climatically forced cycles (Olsen, 1986; Anadón et al., 1991).

\section{CONCLUSIONS}

Tectono-sedimentary interactions in the Oligocene As Pontes Basin resulted in the deposition of a low-order lacustrine sequence (Unit 1), which records the establishment, spreading, deepening and final infilling of a small, tectonically forced lake basin.

The most significant depositional, palaeoenvironmental and palaeohydrological shift identified in the As Pontes lacustrine infill resulted from the coupled influence of tectonic and morphological processes affecting the basin catchment system. Thus, a tectonically driven increase in accommodation space and increasing water input (caused by the headward spread of the watershed) account for the significant deepening and dilution of the lacustrine system and the shifting from a palustrine-lacustrine, shallow ramp-dominated framework to deeper and more stable subaqueous conditions. In addition to this tectonic-morphological forcing, minor oscillations in the water level also influenced the lacustrine sedimentation and gave rise to higher order cycles. These minor oscillations were probably climatically forced and modulated the evolution of the lacustrine system. Therefore, the lower shallow palustrinelacustrine facies (Subunit 1A) were deposited under low and variable water levels (saline and mainly holomictic conditions), which resulted in the deposition of cyclically arranged terrigenous carbonate sequences. The lacustrine sequences in Subunit 1B were also formed mainly under changing but steadier, meromictic, fresh to oligosaline conditions, which favoured the cyclical deposition of fine-grained turbidite beds and clay-carbonate rhythmite bundles.

The sedimentological and geochemical data (i.e. short-term increases in $\mathrm{Mg} / \mathrm{Ca}$ ratio, $\delta^{18} \mathrm{O}$ and $\delta^{13} \mathrm{C}$ covariance trends in calcite, abrupt $\delta^{18} \mathrm{O}$ variations) correspond well with the characteristics of small, closed lakes which, given their sensitivity to climatically forced water balance variations, commonly display very short-term hydrochemical trends.

The research community is already aware that the sedimentary record of ancient lakes provides some of the most complete, high-resolution archives of palaeoclimatic processes. This is because climate is often emphasized as a major control on lacustrine evolution. The present study reinforces the potential of high-resolution ancient lacustrine records to elucidate short-term palaeoclimatic changes. Nevertheless, the analysis of the long-term evolution of the tectonically forced As Pontes Basin illustrates the importance of understanding the style, intensity and timing of tectonic deformation and drainage evolution in order to distinguish properly between tectonic and climatic forcing of the sedimentary record.

\section{ACKNOWLEDGEMENTS}

This research was funded by the Spanish CICYT projects AMB92-311, PB94-0826 and PB97-0882C03-01. Financial support was also provided by ENDESA - Fundació Bosch i Gimpera (projects 207 and 2149). The Grup de Recerca de Qualitat Consolidat of Geodinàmics i Anàlisi de Conques (2001SGR 00074) also supported this research. We thank A. de las Heras for her helpful co-operation in the sampling and analysis of the carbonate samples. P. Anadón, C. Taberner and J. J. Pueyo are gratefully acknowledged for discussions that helped to clarify and improve an earlier version of this paper. The authors are also indebted to M. Talbot, B. Valero-Garcés and P. Mozley for their critical comments and suggestions.

\section{REFERENCES}

Anadón, P. (1989) Los lagos salinos interiores (atalásicos) con faunas de afinidad marina del Cenozoico de la Península Ibérica. Acta Geol. Hisp., 24, 83-102.

Anadón, P. (1992) Composition of inland waters with marinelike fauna and inferences for a Miocene lake in Spain. Palaeogeogr. Palaeoclimatol. Palaeoecol., 99, 1-8.

Anadón, P., Cabrera, L. and Julià, R. (1988) Anoxic-oxic cyclical lacustrine sedimentation in the Miocene Rubielos de Mora Basin, Spain. In: Lacustrine Petroleum Source Rocks (Eds A.J. Fleet, K. Kelts and M.R. Talbot), Geol. Soc. London Spec. Publ., 40, 353-367.

Anadón, P., Cabrera, L., Julià, R. and Marzo, M. (1991) Sequential arrangement and asymmetrical fill in the Miocene Rubielos de Mora Basin (northeast Spain). In: Lacustrine 
Facies Analysis (Eds P. Anadón, L. Cabrera and K. Kelts), Int. Assoc. Sedimentol. Spec. Publ., 13, 257-275.

Andrejko, M.J., Raymond, R. and Cohen, A.D. (1983) Biogenic silica in peats: possible source for chertification in lignites. In: Mineral Matter in Peat: its Occurrence, Form, and Distribution (Eds R. Raymond and M.J. Andrejko), pp. 25-37. Los Alamos National Laboratory, Los Alamos.

Arenas, C., Casanova, J. and Pardo, G. (1997) Stable-isotope characterization of the Miocene lacustrine systems of Los Monegros (Ebro Basin, Spain): palaeogeographic and palaeoclimatic implications. Palaeogeogr. Palaeoclimatol. Palaeoecol., 128, 133-155.

Baltuille, J.M., Becker-Platen, J.D., Benda, L. and Ivanovic, Y. (1992) A contribution to the subdivision of the Neogene in Spain using palynology. Newsl. Stratigr., 27, 41-57.

Barsó, D., Cabrera, L., Marfil, R. and Ramos, E. (2000) Evolución de la procedencia y redes de drenaje de la cuenca terciaria continental de As Pontes (Galicia), a partir del análisis de las modas detríticas y de minerales pesados. Geotemas, 1, 151-154.

Bein, A. (1986) Stable isotopes, iron and phosphorous in a sequence of lacustrine carbonates- Paleolimnic implications. Chem. Geol., 59, 305-313.

Berger, A. and Loutre, M.F. (1994) Astronomical forcing through geological time. In: Orbital Forcing and Cyclic Sequences (Eds P.L. Boer and D.G. Smith), Int. Assoc. Sedimentol. Spec. Publ., 19, 15-24.

Berner, R.A. (1981) A new geochemical classification of sedimentary environments. J. Sed. Petrol., 51, 359-365.

Brewer, R. (1964) Fabric and Mineral Analysis of Soils. John Wiley \& Sons, New York, 470 pp.

Brookins, D.G. (1988) Eh-Ph Diagrams for Geochemistry. Springer Verlag, Berlin, 177 pp.

Cabrera, L., Jung, W., Kirchner, M. and Sáez, A. (1994) Crocodilian and paleobotanical findings from tertiary lignites of As Pontes Basin (Galicia, NW Spain). Courier Frosh. Inst. Senckenb., 173, 153-165.

Cabrera, L., Hagemann, H.W., Pickel, W. and Sáez, A. (1995) The coal bearing Cenozoic As Pontes Basin (NW Spain): geological influence on its coal's characteristics. Int. J. Coal Geol., 27, 201-226.

Cabrera, L., Ferrús, B., Sáez, A., Santanach, P. and Bacelar, J. (1996) Onshore Cenozoic strike-slip basins in NW Spain. In: Spanish Tertiary Basins (Eds P. Friend and C. Dabrio), pp. 247-253. Cambridge University Press, Cambridge.

Cerling, T.E. (1996) Pore water chemistry of an alkaline lake; Lake Turkana, Kenya. In: The Limnology, Climatology and Paleoclimatology of the East African Lakes (Eds J. Thomas and E.O. Odada), pp. 225-240. Gordon and Breach, Australia.

Chung, F.H. (1974) Quantitative interpretation of X-ray diffraction patterns of mixtures. J. Appl. Crystallogr., 7, 519-531.

Clayton, R.N., Jone, B.F. and Berner, R.A. (1968) Isotope studies of dolomite formation under sedimentary conditions. Geochim. Cosmochim. Acta, 32, 415-432.

Cole, J.J., Caraco, N.F., Kling, G.W. and Kratz, T.K. (1994) Carbon dioxide supersaturation in the surface waters of lakes. Science, 265, 1568-1570.

Craig, H. and Gordon, L.I. (1965) Deuterium and oxygen-18 variations in the ocean and marine atmosphere. In: Stable Isotopes in Oceanographic Studies and Palaeotemperatures (Ed. E. Tongiorgi), pp. 9-130. Laboratory of Geology and Nuclear Science, Pisa.

De Deckker, P. and Last, W.M. (1988) Modern dolomite deposition in continental, saline lakes, western Victoria, Australia. Geology, 16, 29-32.
Fernández, R., Moreno, I. and Lozano, A. (1983) Mina de Puentes de García Rodríguez. Estudio Hidrogeológico Previo. Internal report. ENDESA, 142 pp.

Ferrús, B. (1998) Análisis de Cuenca y Relaciones TectónicaSedimentación en la Cuenca de as Pontes (Galicia). PhD Thesis, University of Barcelona, $351 \mathrm{pp}$.

Fontes, J.C., Maglione, G. and Roche, M.A. (1970) Elements d'hydrologie isotopique dans le bassin du lac Tchad. In: Peaceful Uses of Atomic Energy in Africa, pp. 209-222. IAEA, Vienna.

Freytet, P. and Plaziat, J.C. (1982) Continental carbonate sedimentation and pedogenesis. Late Cretaceous and Early Tertiary of Southern France. In: Contributions to Sedimentology 12 (Ed. B.H. Purser). Schweizerbart, Stuttgart, $217 \mathrm{pp}$.

Fritz, P. and Smith, D.G.W. (1970) The isotopic compositions of secondary dolomites. Geochim. Cosmochim. Acta, 34, 1161-1173.

Hardie, L.A., Smoot, J.P. and Eugster, H.P. (1978) Saline lakes and their deposits: a sedimentological approach. In: Modern and Ancient Lake Sediments (Eds A. Matter and M. Tucker), Int. Assoc. Sedimentol. Spec. Publ., 2, 7-41.

Hsü, K.J. and Kelts, K. (1978) Late Neogene chemical sedimentation in the Black Sea. In: Modern and Ancient Lake Sediments (Eds A. Matter and M. Tucker), Int. Assoc. Sedimentol. Spec. Publ., 2, 129-145.

Huerta, A., Parés, J.M., Cabrera, L., Ferrús, B. and Sáez, A. (1997) Magnetoestratigrafía de las sucesiones cenozoicas de la cuenca de As Pontes (La Coruña, NW Spain). Acta Geol. Hisp., 32, 127-145.

Hyman, L.H. (1967) The Invertebrates, Vol. VII. Molluscs. McGraw-Hill, New York, 792 pp.

Johnson, T.C., Halfman, J.D. and Showers, J. (1991) Paleoclimate of the past 4000 years at Lake Turkana, Kenya, based on the isotopic composition of authigenic calcite. Palaeogeogr. Palaeoclimatol. Palaeoecol., 85, 189-198.

Land, L.S. (1985) The origin of massive dolomite. J. Geol. Educ., 33, 112-125.

Lasemi, Z. and Sandberg, P.A. (1993) Microfabric and compositional clues to dominant mud mineralogy of micritic precursors. In: Carbonate Microfabrics (Ed. R. Rezak), pp. 173-185. Springer Verlag, Berlin.

Last, W. (1990) Lacustrine dolomite; an overview of modern, Holocene, and Pleistocene occurrences. Earth-Sci. Rev., 27, 221-263.

Li, H.C. and Ku, T.L. (1997) $\delta^{13} \mathrm{C}-\delta^{18} \mathrm{O}$ covariance as a paleohydrological indicator for closed-basin lakes. Palaeogeogr. Palaeoclimatol. Palaeoecol., 133, 69-80.

Lister, G.S., Kelts, K., Chen, Ke Zao, Jun-Qing, Yu and Niessen, F. (1991) Lake Qinghai, China: closed-basin lake levels and the oxygen isotope record for ostracoda since the latest Pleistocene. Palaeogeogr. Palaeoclimatol. Palaeoecol., 8, 141-162.

Lumsden, D.N. (1979) Discrepancy between thin section and X-ray estimates dolomite in limestone. J. Sed. Petrol., 49, 429-436.

McCrea, J.M. (1950) On the isotopic chemistry of carbonates and a paleotemperature scale. J. Chem. Phys., 18, 849857.

McKenzie, J.A. (1985) Carbon isotopes and productivity in the lacustrine and marine environment. In: Chemical Processes in Lakes (Ed. W. Stumm), pp. 99-118. Wiley, New York.

Matthews, A. and Katz, A. (1977) Oxygen isotope fractionation during dolomitization of calcium carbonate. Geochim. Cosmochim. Acta, 41, 1431-1438. 
Medus, J. (1965) L'Evolution biostratigraphique d'une lagune néogène de Galicie (Espagne). Pollen Spores, VII, 381-393.

Mozley, P.S. and Wersin, P. (1992) Isotopic composition of siderite as an indicator of depositional environment. Geology, 20, 817-820.

Müller, G. and Wagner, F. (1978) Holocene carbonate evolution in Lake Balaton (Hungary): a response to climate and impact of man. In: Modern and Ancient Lake Sediments (Eds A. Matter and M. Tucker), Int. Assoc. Sedimentol. Spec. Publ., 2, 57-81.

Olsen, P.E. (1986) A 40-million year lake record of Early Mesozoic orbital climatic forcing. Science, 234, 842-848.

Platt, N.H. and Wright, P.V. (1991) Lacustrine carbonates: facies models, facies distributions and hydrocarbon aspects. In: Lacustrine Facies Analysis (Eds P. Anadón, L. Cabrera and K. Kelts), Int. Assoc. Sedimentol. Spec. Publ., 13, 57-74.

Plaziat, J.C. (1993) Modern and fossil Potamids (Gastropoda) in saline lakes. J. Paleolimnol., 8, 163-169.

Sofer, Z. and Gat, J.R. (1975) The isotope composition of evaporating brines: effect of the isotopic activity ratio in saline solutions. Earth Planet. Sci. Lett., 26, 179-186.

Talbot, M.R. (1990) A review of the paleohydrological interpretation of carbon and oxygen isotopic ratios in primary lacustrine carbonates. Chem. Geol., 80, 261-279.

Talbot, M.R. and Kelts, K. (1990) Paleolimnological signatures from carbon and oxygen isotopic ratios in carbonates from organic-rich lacustrine sediments. In: Lacustrine Exploration: Case Studies and Modern Analogues (Ed. B.J. Katz), AAPG Mem., 50, 99-112.

Turner, J.V., Fritz, P., Karrow, P.F. and Warner, B.G. (1983) Isotopic and geochemical composition of marl lake waters and implications for radiocarbon dating of marl lake sediments. Can. J. Earth Sci., 20, 599-615.
Utrilla, R., Vazquez, A. and Anadón, P. (1998) Paleohydrology of the Upper Miocene Bicorb Lake (eastern Spain) as inferred from stable isotopic data from inorganic carbonates. Sed. Geol., 121, 91-206.

Valero-Garcés, B.L., Kelts, K. and Ito, E. (1995) Oxygen and carbon isotope trends and sedimentological evolution of a meromictic and saline lacustrine system: the Holocene Medicine Lake basin, North American Great Plains, USA Palaeogeogr. Palaeoclimatol. Palaeoecol., 117, 253-278.

Valero-Garcés, B.L., Laird, K.R., Fritz, S., Kelts, K., Ito, E. and Grimm, E.C. (1997) Holocene climate in the Northern Great Plains inferred from Sediment stratigraphy, stable isotopes, carbonate geochemistry, diatoms and pollen at Moon Lake, North Dakota. Quatern. Res., 48, 359-369.

Wachniew, P. and Rozanski, K. (1997) Carbon budget of a mid-latitude, groundwater lake: isotopic evidence for the importance of dissolved inorganic carbon recycling. Geochim. Cosmochim. Acta, 61, 2453-2465.

Wetzel, R.G. (1983) Limnology, 2nd edn. W.B. Saunders, Philadelphia, 767 pp.

Wright, V.P., Alonso-Zarza, A.M., Sanz, M.E. and Calvo, J.P. (1997) Diagenesis of Late Miocene micritic lacustrine carbonates, Madrid Basin, Spain. Sed. Geol., 113, 81-95.

Wuttke, M. (1992) Conservation-dissolution-transformation. On the behavior of biogenic materials during fossilization. In: Messel. An Insight Into the History of Life and of the Earth (Eds S. Schaal and W. Ziegler), pp. 265-275. Clarendon Press, Oxford.

Manuscript received 25 July 2000; revision accepted 23 May 2002. 